\title{
Impact of the Fukushima accident on tritium, radiocarbon and radiocesium levels in seawater of the western North Pacific Ocean: a comparison with pre-Fukushima situation
}

\begin{abstract}
Tritium, radiocarbon and radiocesium concentrations in water column samples in coastal waters offshore Fukushima and in the western North Pacific Ocean collected in 2011-2012 during the Ka'imikai-o-Kanaloa (KoK) cruise are compared with other published results. The highest levels in surface seawater were observed for ${ }^{134} \mathrm{Cs}$ and ${ }^{137} \mathrm{Cs}$ in seawater samples collected offshore Fukushima (up to $1.1 \mathrm{~Bq} \mathrm{~L}^{-1}$ ), which represent an increase by about three orders of magnitude when compared with the pre-Fukushima concentration. Tritium levels were much lower (up to $0.15 \mathrm{~Bq} \mathrm{~L}^{-1}$ ), representing an increase by about a factor of 6 . The impact on the radiocarbon distribution was measurable, but the observed levels were only by about $9 \%$ above the global fallout background. The ${ }^{137} \mathrm{Cs}$ (and similarly ${ }^{134} \mathrm{Cs}$ ) inventory in the water column of the investigated western North Pacific region was $(2.7 \pm 0.4) \mathrm{PBq}$, while for ${ }^{3} \mathrm{H}$ it was only $(0.3 \pm 0.2) \mathrm{PBq}$. Direct releases of highly contaminated water from the damaged Fukushima NPP, as well as dry and wet depositions of these radionuclides over the western North Pacific considerably changed their distribution patterns in seawater. Presently we can distinguish Fukushima labeled waters from global fallout background thanks to short-lived ${ }^{134} \mathrm{Cs}$. However, in the long-term perspective when ${ }^{134} \mathrm{Cs}$ will decay, new distribution patterns of ${ }^{3} \mathrm{H},{ }^{14} \mathrm{C}$ and ${ }^{137} \mathrm{Cs}$ in the Pacific Ocean should be established for future oceanographic and climate change studies in the Pacific Ocean.
\end{abstract}

Keywords: Fukushima accident; radionuclides in seawater; KoK cruise; GEOSECS; WOCE; WOMARS 


\section{Introduction}

Large quantities of radionuclides were released during the Fukushima Dai-chi Nuclear Power Plant (NPP) accident (starting on 11 March 2011) to the atmosphere (Chino et al., 2011; Hirose, 2012) and to coastal waters (Kawamura et al., 2011; Povinec et al., 2013a; Aoyama et al. 2015a, b). From a radiological point of view, ${ }^{137} \mathrm{Cs}$ has been considered to be the most important anthropogenic radionuclide in the environment because of its large releases, relatively long half-life, and its relative high bioavailability. Due to its accumulation in tissues, it has been relevant for delivering radiation doses to the public from the consumption of food (Aarkrog et al., 1997; Livingston and Povinec, 2000). Another radioecologically important radionuclide, which may be released in large quantities during nuclear accidents is ${ }^{131} \mathrm{I}$, however, because of its short half-life (8.02 days), its contribution is dominant to terrestrial radiation doses during first days after the accident (Povinec et al., 2013a).

About $15-20 \mathrm{PBq}$ of radiocesium (for ${ }^{134} \mathrm{Cs}$ and ${ }^{137} \mathrm{Cs}$ each) was released during the Fukushima accident to the atmosphere (Chino et al., 2011; Povinec et al., 2013a, b; Aoyama et al. 2015a), which occurred mainly between 12 and 16 March, with smaller contributions up to March 24. Most of the radionuclides released to the atmosphere were rapidly associated with aerosols, representing a major form of pollutants in the atmosphere, which have been then distributed globally (Masson et al., 2011; Povinec et al., 2013a, b). The radionuclides moved with the prevailing western winds mainly from Fukushima over the Pacific Ocean (Povinec et al., 2013c), with only a partial contamination of the Japanese land (Hirose, 2012) and the Japan Sea (Inoue et al., 2012).

After passing the Pacific Ocean, North America, the Atlantic Ocean, and Europe, the radioactive clouds went back across the Asian continent. At the beginning of April 2011, the northern hemisphere was labeled with Fukushima-derived radionuclides (Masson et al., 2011; Hernández-Ceballos et al., 2012; Povinec et al., 2013a, b). The aerosols with captured radionuclides were then deposited on the Earth's surface including the ocean by wet and dry deposition. About $80 \%$ was deposited over the North Pacific Ocean, about $20 \%$ over Japan, and less than 2\% over the Atlantic and Europe (Morino et al., 2011; Stohl et al., 2012; Yoshida and Kanda, 2012).

We shall discuss in this paper radionuclide variations in the water column of the western North Pacific Ocean after the Fukushima accident. Distribution of several radionuclides dissolved in seawater (e.g., ${ }^{3} \mathrm{H},{ }^{90} \mathrm{Sr},{ }^{129} \mathrm{I},{ }^{134} \mathrm{Cs},{ }^{137} \mathrm{Cs}$ ) has already been under investigations (e.g., Aoyama et al., 2012, 2013, 2015a; Buesseler et al., 2012; Hou et al. 2013; Povinec et 
al., 2012, 2013a, d). We shall focus in this paper on Fukushima inpact on ${ }^{3} \mathrm{H},{ }^{14} \mathrm{C}$ and radiocesium levels in water column of the western North Pacific Ocean.

Cesium radioisotopes, namely ${ }^{137} \mathrm{Cs}$ (half-life $\mathrm{T}_{1 / 2}=30.17 \mathrm{yr}$ ) and ${ }^{134} \mathrm{Cs}\left(\mathrm{T}_{1 / 2}=2.06 \mathrm{yr}\right.$ ) have been the most frequently studied radionuclides in seawater after the Fukushima accident. Presence of ${ }^{134} \mathrm{Cs}$ in seawater clearly indicates its Fukushima origin as because of the short half-life ${ }^{134} \mathrm{Cs}$ from global fallout and the 1986 Chernobyl accident has already decayed. The nuclear accident at the Fukushima Dai-ichi NPP increased ${ }^{137} \mathrm{Cs}$ concentrations in coastal seawater in March 2011 up to $68 \mathrm{kBq} \mathrm{L}^{-1}$, eight orders of magnitude above the global fallout background (Povinec et al., 2013a; Povinec and Hirose, 2015). This increase was due to direct liquid releases of ${ }^{137} \mathrm{Cs}$ contaminated fresh and later also seawater to coastal waters, which was estimated to be around 4 PBq (Kawamura et al., 2011; Tsumune et al., 2012, 2013; Aoyama et al., 2016a, b). The ${ }^{131} 1 /{ }^{137} \mathrm{Cs}$ activity ratio in surface seawater offshore Fukushima indicated that most of the radiocesium observed in coastal waters was the result of a direct discharge to the ocean (Hou et al., 2013). Due to the transport of water masses from the Japanese coast to the open western North Pacific by the coastal currents (Nakano and Povinec, 2003, 2012; Tsumune et al., 2012, 2013), the high ${ }^{137} \mathrm{Cs}$ concentrations observed in 2011 in coastal seawater decreased rapidly with apparent half-life of about 1 year (Povinec and Hirose, 2015). The typical ${ }^{137}$ Cs activity concentrations in coastal waters in 2011-2012 were from a few $\mathrm{mBq} \mathrm{L}^{-1}$ to a few $\mathrm{Bq} \mathrm{L}^{-1}$ (Aoyama et al., 2012, 2013; Buesseler et al., 2012; Honda et al., 2012; Povinec et al. 2013a, d; Kameník et al., 2013; Kumamoto et al., 2013a).

Only a little attention has been given till now to tritium (Povinec et al., 2013a, d; Matsumoto et al., 2013; Steinhauser, 2014), mainly because of the fact that liquid tritium releases when compared with radiocesium were much lower (0.1-0.5 PBq; Povinec et al., 2013d). Radiological impact due to tritium is low because of its short physical half-life (12.32 y), its short effective biological half-life in the human body (10 days, Kim et al., 2011), the low energy of emitted beta-decay electrons $(18.6 \mathrm{keV})$ and its low production rates in nuclear reactors (Chudý and Povinec, 1982; Povinec et al., 2013a).

Similarly a radiological impact of radiocarbon on the marine environment and on humans has been expected to be low due to its low production rates in nuclear reactors (Chudý and Povinec, 1982). When compared with the Chernobyl accident, where due to ${ }^{14} \mathrm{C}$ production in the graphite moderator in the ${ }^{13} \mathrm{C}(\mathrm{n}, \gamma){ }^{14} \mathrm{C}$ reaction, and the graphite burning during the accident, the ${ }^{14} \mathrm{C}$ release to the atmosphere was estimated to be around $44 \mathrm{TBq}$ (Povinec et al., 2013a). Elevated ${ }^{14} \mathrm{C}$ levels (up to $124 \mathrm{pMC}$ (\% Modern Carbon) or $281.6 \mathrm{~Bq} \mathrm{~kg}^{-1}$ of carbon) were measured in tree rings collected about $2.5 \mathrm{~km}$ from the Chernobyl NPP (Buzinny et al. 
1998). However, the ${ }^{14} \mathrm{C}$ effect was not measurable in Central Europe (Povinec et al., 1988). There are no data available on radiocarbon in the atmosphere or in seawater after the Fukushima accident.

The aim of the present study has been to assess, compare and evaluate tritium, radiocarbon and radiocesium records in the water column of the western North Pacific Ocean after the Fukushima accident. It has been important to estimate changes in ${ }^{3} \mathrm{H},{ }^{14} \mathrm{C}$ and ${ }^{137} \mathrm{Cs}$ concentrations in Pacific waters after the Fukushima accident not only from a radioecological point of view, but also due to the fact that these radionuclides have been frequently used as tracers of ocean and ocean-atmosphere processes. We need to know how radionuclide concentrations have changed in the Pacific Ocean after the Fukushima accident, and how we can apply pre-Fukushima and post-Fukushima data in oceanographic research. The observed radionuclide patterns and their comparison with pre-Fukushima data will contribute to future oceanographic and climate studies using these radionuclides as tracers of processes in the marine environment.

The radionuclide data presented in this paper were obtained from analyses of seawater samples collected during the KoK (Ka'imikai-o-Kanaloa) cruise, carried out in June 2011 offshore Fukushima. Preliminary data on tritium and radiocesium (mostly surface samples) were discussed in our previous paper (Povinec et al., 2013d). In the present paper we discuss the final data set on tritium (21 results) and radiocesium (45 results), together with 12 radiocarbon results (Table 1). A comprehensive radiocesium data set, covering the KoK seawater sampling, has been published by Buesseler et al. (2012). In this paper we report complementary ${ }^{3} \mathrm{H},{ }^{14} \mathrm{C},{ }^{134} \mathrm{Cs}$ and ${ }^{137} \mathrm{Cs}$ data, and compare them with recently published postFukushima radiocesium data (Aoyama et al., 2012a,b; 2013; 2015a, b; Buesseler et al., 2012; Kaeriyama et al., 2013; Kumamoto et al., 2013a, 2014, 2015), as well as with pre-Fukushima ${ }^{3} \mathrm{H},{ }^{14} \mathrm{C}$ and ${ }^{137} \mathrm{Cs}$ data obtained for the western North Pacific Ocean (Ostlund et al., 1987; Watanabe et al., 1991; Tsunogai et al., 1995; Aramaki et al., 2001; Kumamoto et al., 2002; Povinec et al. 2003, 2004c, 2010).

\section{Direct releases and atmospheric deposition of ${ }^{137} \mathrm{Cs},{ }^{3} \mathrm{H}$ and ${ }^{14} \mathrm{C}$ during the Fukushima} accident to the western North Pacific Ocean

\subsection{Radiocesium}


138 The largest radionuclide releases to the coastal ocean were due ${ }^{137} \mathrm{Cs}$ because of its large 139 production rates in the damaged Fukushima nuclear reactors (yield $6.2 \%$ ). The ${ }^{137} \mathrm{Cs}$ 140 inventory in the damaged nuclear reactors has been estimated to be about $700 \mathrm{PBq}(230 \mathrm{PBq}$ 141 recovered), and $140 \mathrm{PBq}$ in stagnant water (Povinec et al., 2013a). The ${ }^{134} \mathrm{Cs}$ production in the 142 damaged Fukushima nuclear reactors was similar to that of ${ }^{137} \mathrm{Cs}$, therefore its inventory and 143 the direct ${ }^{134} \mathrm{Cs}$ releases to the sea were estimated to be similar to ${ }^{137} \mathrm{Cs}$ ones on the basis of 144 their activity ratio close to one (Kirchner et al., 2012).

\subsubsection{Direct releases of radiocesium to the sea}

Kawamura et al. (2011) using the TEPCO (Tokyo Electric Power Company) data and numerical simulations estimated the total ${ }^{137} \mathrm{Cs}$ release for the period from 21 March to 30 April 2011 to be 4 PBq. Tsumune et al. (2013) using a global ocean circulation model and the available ${ }^{137} \mathrm{Cs}$ monitoring data estimated the direct ${ }^{137} \mathrm{Cs}$ releases between 26 March and 31 May 2011 to be $3.5 \pm 0.7 \mathrm{PBq}$. Similar estimations were obtained using various oceanic models: 1-3.5 PBq by Dietze and Kriest (2012), 4.1-4.5 PBq by Estournel et al. (2012), and 5.5-5.9 PBq by Miyazawa et al. (2012a, b). Recently Aoyama et al. (2015a, b) critically reviewed the different ${ }^{137} \mathrm{Cs}$ release rate scenarios, and their best estimation is $3.6 \pm 0.7 \mathrm{PBq}$.

\subsubsection{Deposition of radiocesium over the Pacific Ocean}

158

159

The estimation of the atmospheric deposition of ${ }^{137} \mathrm{Cs}$ over the Pacific Ocean is even more difficult task in the evaluation of its source term in the ocean (Kawamura et al., 2011; Morino et al., 2011; Buesseler et al., 2012; Stohl et al., 2012; Honda et al., 2012; Rypina et al., 2013). Dietze and Kriest (2012) estimated the accumulated atmospheric deposition of ${ }^{137} \mathrm{Cs}$ in the range of $50-200 \mathrm{kBq} \mathrm{m}^{-2}$. It has been expected therefore that the wet and dry deposition over the huge Pacific Ocean may dominate over the radiocesium transport from coastal waters to the open ocean (Aoyama et al., 2015a, b). Rypina et al. (2013) using the KoK data estimated the contribution from the atmospheric source to be in the range of $0-11 \mathrm{PBq}$. The KoK data are, however, not well-suited for constraining the atmospheric source strength because of the restricted sampling area (only about $600 \mathrm{~km}$ east from the coast), and the fact that most of the Fukushima fallout ${ }^{137} \mathrm{Cs}$ had left the survey area by mid-June when the KoK sampling cruise was carried out. Aoyama et al. (2015b) recently reviewed the available data 
171 and came with the estimation that the ${ }^{137}$ Cs wet and dry deposition over the North Pacific

172 Ocean should be in the range of $12-15 \mathrm{PBq}$ from the total atmospheric release of 14-17 PBq.

173

174

175

176

177

178

179

180

181

182

183

184

185

186

187

188

189

190

191

192

193

194

195

196

197

198

199

200

201

202

203

\subsection{Tritium}

Tritium production in the Fukushima boiling-water reactors was mainly due to a ternary fission of ${ }^{235} \mathrm{U}$ (yield of $0.013 \%$ ) and of ${ }^{239} \mathrm{Pu}\left(0.023 \%\right.$ ), with the estimated annual ${ }^{3} \mathrm{H}$ production of about $1 \mathrm{PBq} / \mathrm{GW}_{\mathrm{e}}$ (Povinec et al., 2013a). Tritium was also produced in nuclear reactions with ${ }^{10} \mathrm{~B}$ in boron carbide control rods

$$
\begin{aligned}
& { }^{10} \mathrm{~B}(\mathrm{n}, 2 \alpha){ }^{3} \mathrm{H} \\
& { }^{10} \mathrm{~B}(\mathrm{n}, \alpha){ }^{7} \mathrm{Li} \Rightarrow{ }^{7} \mathrm{Li}(\mathrm{n}, \alpha \mathrm{n}){ }^{3} \mathrm{H} .
\end{aligned}
$$

Further, the ${ }^{3} \mathrm{H}$ production was also due to the neutron capture reaction on deuterium present in the water coolant $\left({ }^{2} \mathrm{H}(\mathrm{n}, \gamma){ }^{3} \mathrm{H}\right)$ and in the reaction ${ }^{7} \mathrm{Li}(\mathrm{n}, \alpha \mathrm{n}){ }^{3} \mathrm{H}$ on lithium impurities in the water. The nuclear reaction contributions to the annual ${ }^{3} \mathrm{H}$ production were, however, much smaller (about $0.1 \mathrm{TBq} / \mathrm{GW}_{\mathrm{e}}$ ) than the ternary fission. Tritium will not be released at once even if the fuel and the boron control rods would be damaged. Generally, boiling-water nuclear reactors produce less tritium than pressurized water reactors and much less than heavy water reactors (Chudý and Povinec, 1982; Povinec et al., 2013a).

The ${ }^{3} \mathrm{H}$ inventory in three damaged nuclear reactors was estimated to be about $3.4 \mathrm{PBq}(1-$ 1.2 PBq in each reactor; Nishihara et al., 2012; http://www.meti.go.jp/earthquake/ nuclear/pdf/140424/140424_02_008.pdf), much higher than the value of 0.018 PBq reported by Schwantes et al. (2012). From the total of $3.4 \mathrm{PBq}$ produced tritium, about $0.8 \mathrm{PBq}$ was stored in tanks, about $0.05 \mathrm{PBq}$ was in stagnant water accumulated in the reactors and turbines buildings, and about $0.05 \mathrm{PBq}$ was in seawater pipe trenches. Rest of the tritium inventory should be in the fuel debris, and part of it was released directly to the sea.

The ${ }^{3} \mathrm{H}$ activity concentration in stagnant water in June 2011 was in the range 0.7-20 MBq $\mathrm{L}^{-1}$ (lower by a factor of about $10^{5}$ when compared e.g. with heavy water reactors). The release ratio from nuclear cores to the stagnant water was estimated to be the highest for ${ }^{3} \mathrm{H}$ $(46 \%),{ }^{131} \mathrm{I}$ (32\%), and ${ }^{137} \mathrm{Cs}(20 \%)$, but only $1.6 \%$ for ${ }^{90} \mathrm{Sr}$ (Nishihara et al., 2012). This would indicate that the maximal direct releases to the sea could be for ${ }^{131} \mathrm{I},{ }^{137} \mathrm{Cs},{ }^{90} \mathrm{Sr}$ and ${ }^{3} \mathrm{H}$, of about 1900,140, $8 \mathrm{PBq}$ and 1.6, respectively (if all the stagnant water would be released to the sea). The ${ }^{3} \mathrm{H} /{ }^{137} \mathrm{Cs}$ and ${ }^{3} \mathrm{H} /{ }^{90} \mathrm{Sr}$ activity ratios in the stagnant water were $7 \times 10^{-3}$ and 0.2 , respectively, which could be expected in coastal waters as well. Additionally, during the 
accident, external cooling with fresh and later also with seawater was carried out, which could also increase radionuclide levels in coastal waters.

At present the total water volume in storage tanks at the Fukushima NPP site is about $460,000 \mathrm{~m}^{3}$, which is undergoing decontamination (except for tritium) in a Multi-Nuclide Removal System (ALPS), with typical ${ }^{3} \mathrm{H}$ activity concentrations of $800 \mathrm{kBq} \mathrm{L}^{-1}$ (Povinec et al., 2013a). It is very likely that the tritiated water will be discharged to the sea, or evaporated and released to the atmosphere.

Unfortunately, there are no data available on tritium levels during the early stage of the Fukushima NPP accident at the seaport, close to discharge points. The TEPCO reported for August 2013 a value of $68 \mathrm{~Bq} \mathrm{~L}^{-1}$ (www.TEPCO.com). We shall estimate the total amount of ${ }^{3} \mathrm{H}$ released to coastal waters and deposited over the North Pacific Ocean later when we shall calculate both the ${ }^{137} \mathrm{Cs}$ and ${ }^{3} \mathrm{H}$ inventories in the water column. A preliminary estimation of the total ${ }^{3} \mathrm{H}$ releases to the marine environment (using a very limited data set) was in the range of 0.1-0.5 PBq (Povinec et al., 2013d). Estimation of the ${ }^{3} \mathrm{H}$ source term in the western North Pacific Ocean depends strongly on the estimations of direct liquid releases and atmospheric depositions of ${ }^{137} \mathrm{Cs}$ on the studied sea areas. Therefore with improving our knowledge of the ${ }^{137} \mathrm{Cs}$ source term, the estimation of the ${ }^{3} \mathrm{H}$ source term will also improve.

Generally, the tritium inventory should be much smaller when compared with global fallout and with natural production of tritium. The total bomb produced tritium inventory was estimated to be around $186 \mathrm{EBq}$ in the atmosphere and $113 \mathrm{EBq}$ in the ocean, from which 8 EBq was still present in 2010 (Povinec et al., 2010, 2013a). The inventory of ${ }^{3} \mathrm{H}$ discharged from reprocessing nuclear facilities to the ocean was $410 \mathrm{PBq}$, from which $45 \mathrm{PBq}$ was still present in 2010. The annual cosmic-ray production, predominantly in the reactions

$$
{ }^{14} \mathrm{~N}\left(\mathrm{n},{ }^{3} \mathrm{H}\right){ }^{12} \mathrm{C} \text { and }{ }^{16} \mathrm{O}\left(\mathrm{n},{ }^{3} \mathrm{H}\right){ }^{14} \mathrm{~N}
$$

is much lower, around $0.15 \mathrm{EBq}$, varying with cosmic-ray flux. The world steady-stay natural inventory is about $2.2 \mathrm{EBq}$.

\subsection{Radiocarbon}

There are no data available on radiocarbon source term, and on its gaseous and liquid releases after the Fukushima accident. Radiocarbon is an activation product formed mainly in the ${ }^{14} \mathrm{~N}$ (n, p) ${ }^{14} \mathrm{C}$ and ${ }^{17} \mathrm{O}(\mathrm{n}, \alpha){ }^{14} \mathrm{C}$ nuclear reactions on target nuclei present in the fuel, and on impurities in the fuel rods and in the coolant/moderator (Chudý and Povinec, 1982). The ${ }^{14} \mathrm{C}$ is also produced in ternary fission (with yield of $1.6 \times 10^{-4} \%$ ), however, its contribution is 
negligible when compared with nuclear reactions. For the BWR reactors the dominant annual production is on ${ }^{14} \mathrm{~N}$ impurities in the fuel, in the rods and in the water coolant $\left(1.3 \mathrm{TBq} / \mathrm{GW}_{\mathrm{e}}\right)$ and on ${ }^{17} \mathrm{O}$ present in the fuel and in the water coolant $\left(0.7 \mathrm{TBq} / \mathrm{GW}_{\mathrm{e}}\right)$. The total annual ${ }^{14} \mathrm{C}$ production in BWRs is estimated to be around $2 \mathrm{TBq} / \mathrm{GW}_{\mathrm{e}}$, from which about $1.2 \mathrm{TBq} / \mathrm{GWe}$ should be present in the fuel rods, and about $0.8 \mathrm{TBq} / \mathrm{GWe}$ in the water coolant (Povinec et al., 2013a).

Generally, the production rates of Fukushima-derived radiocarbon should be negligible when compared with bomb produced radiocarbon, and its natural production by cosmic rays. The radiocarbon inventory due to atmospheric nuclear bomb tests was about $213 \mathrm{PBq}$ in the atmosphere and about $130 \mathrm{PBq}$ in the ocean (UNSCEAR, 2008). The ${ }^{14} \mathrm{C}$ inventory from discharges from reprocessing nuclear facilities was about $2 \mathrm{PBq}$, mostly in the marine environment (Povinec et al., 2000). The natural ${ }^{14} \mathrm{C}$ is produced in the atmosphere by cosmicray neutrons in the same reactions as mentioned above, the dominant reaction being ${ }^{14} \mathrm{~N}(\mathrm{n}, \mathrm{p})$ ${ }^{14} \mathrm{C}$. The annual ${ }^{14} \mathrm{C}$ production is about $1.4 \mathrm{PBq}$, which vary with the cosmic-ray flux. The total inventory is about $8.5 \mathrm{EBq}$, of which about $0.14 \mathrm{EBq}$ is in the atmosphere and rest is mostly in oceans (UNSCEAR, 2008).

\section{Samples and methods}

\subsection{Seawater samples}

Seawater samples were collected offshore Fukushima during the US expedition using the research vessel Ka'imikai-o-Kanaloa (KoK) of the University of Hawaii (3-17 June, 2011) from about $30 \mathrm{~km}$ to about $600 \mathrm{~km}$ (from 34 to $38^{\circ} \mathrm{N}$, and from 141.5 to $147^{\circ} \mathrm{E}$ ) east of the Japan coast (Buesseler et al., 2012). Locations of KoK sampling stations used in this study are shown in Fig. 1a. Water column sampling stations, visited during other cruises (which have been used for comparison) are shown in Fig. 1 b.

Surface samples for radionuclide analyses were collected using a water pump. Water column samples were collected at different depths using a Rosette sampling system equipped with Niskin bottles. Half liter of seawater was used both for ${ }^{3} \mathrm{H}$ and ${ }^{14} \mathrm{C}$ analyses, while ${ }^{137} \mathrm{Cs}$ was analyzed in $1 \mathrm{~L}$ seawater samples. The bottles had double plugs to prevent a penetration of air into the water sample during transport and storage. Surface seawater samples were collected at 17 stations, and water profile samples at 12 stations. 


\subsection{Tritium analysis}

Pre-screening of ${ }^{3} \mathrm{H}$ levels in seawater samples (to avoid possible contamination) was carried out in the Bratislava laboratory by direct ${ }^{3} \mathrm{H}$ counting (after triple distillation) in water-liquid scintillator cocktails using Packard liquid scintillation spectrometer. Tritium was then precisely analyzed in seawater samples in the Debrecen and Saclay laboratories using the ${ }^{3} \mathrm{He}$ in-growth mass spectrometry method. The procedure used in Debrecen (Palcsu et al., 2010) consists of three major steps: First, the water sample is put into a stainless steel vessel, and the dissolved gases including helium are removed from the water by vacuum pumping. The samples are then stored for several months so that ${ }^{3} \mathrm{He}$ atoms are produced by tritium decay. The helium fraction is finally admitted to a dual collector noble gas mass spectrometer, where the abundance of the tritiogenic ${ }^{3} \mathrm{He}$ is measured, and ${ }^{3} \mathrm{H}$ activity is calculated.

In the procedure used in Saclay (Jean-Baptiste et al., 2010) the water samples were transferred and sealed in low helium diffusivity glass bulbs that had been previously baked at $600^{\circ} \mathrm{C}$ under a stream of argon. After an equilibrium time of about 100-150 days, the bulbs were then connected to a MAP-215-50 noble gas mass spectrometer equipped with a stainless steel low blank inlet system $\left({ }^{3} \mathrm{He}\right.$ blank $\left.<3 \times 10^{-20} \mathrm{~mol}\right)$ for measurements that were calibrated against an air standard $\left(\mathrm{He}=5.24 \mathrm{ppm},{ }^{3} \mathrm{He} /{ }^{4} \mathrm{He}=1.38 \times 10^{-6}\right)$ drawn from a $5 \mathrm{~L}$ tank filled with clean air at known pressure, temperature and relative humidity conditions, through a precisely calibrated volume of $122.2 \pm 0.1$ (at 2 sigma) $\mathrm{mm}^{3}$. The ${ }^{3} \mathrm{He}$ ingrowth method can measure ${ }^{3} \mathrm{H}$ levels down to $0.01 \mathrm{TU}$ (precision at $1 \sigma$ is around $0.005 \mathrm{TU}$ ).

It has been widely accepted in oceanographic studies that tritium levels has been reported in Tritium Units (TU). One TU represents an isotope ratio of $1{ }^{3} \mathrm{H}$ atom to $10^{18}$ protium $\left({ }^{1} \mathrm{H}\right)$ atoms, which is equivalent to $0.118 \mathrm{~Bq} \mathrm{~L}^{-1}$ of water.

\subsection{Radiocarbon analysis}

The ${ }^{14} \mathrm{C}$ measurements from dissolved inorganic carbon (DIC) of the seawater samples were carried out using an accelerator mass spectrometry (AMS) in the Debrecen laboratory. However, to avoid a possible ${ }^{14} \mathrm{C}$ contamination of the AMS system, a few seawater samples with highest ${ }^{137} \mathrm{Cs}$ levels were checked for ${ }^{14} \mathrm{C}$ content in the Bratislava laboratory by a gas proportional counting technique (Povinec et al., 2013e). For AMS analyses, the dissolved $\mathrm{CO}_{2}$ was extracted from $20 \mathrm{~mL}$ seawater samples by adding $85 \%$ phosphoric acid, followed by 2 hours heating at $75{ }^{\circ} \mathrm{C}$ in a heating block. The degassed $\mathrm{CO}_{2}$ was extracted and 
cryogenically cleaned in a vacuum line (Molnár et al., 2013a). The obtained pure $\mathrm{CO}_{2}$ gas was then converted to graphite by sealed tube graphitization method (Rinyu et al., 2013). The ${ }^{14} \mathrm{C}$ measurements from the graphite targets were performed with a MICADAS type AMS in the Debrecen laboratory (Molnár et al., 2013b). The overall measurement uncertainty for each sample was below 5\%, including normalization, background subtraction, and counting statistics. The ${ }^{14} \mathrm{C}$ results were corrected for decay of the standard and for isotope fractionation using ${ }^{13} \mathrm{C}$ measurements.

The ${ }^{14} \mathrm{C}$ concentration is given as $\Delta^{14} \mathrm{C}$ (in \%), relative to the NIST (National Institute of Standards and Technology, Gaithersburg, USA) ${ }^{14} \mathrm{C}$ oxalic acid standard (Stuiver and Ostlund, 1983)

$$
\begin{aligned}
& \Delta^{14} \mathrm{C}=\delta^{14} \mathrm{C}-2\left(\delta^{13} \mathrm{C}+25\right)\left(1+\delta^{14} \mathrm{C} / 1000\right)(\%) \\
& \delta^{14} \mathrm{C}=\delta^{14} \mathrm{C}=\left[\left({ }^{14} \mathrm{C}_{\text {sample }}-{ }^{14} \mathrm{C}_{\text {standard }}\right) /{ }^{14} \mathrm{C}_{\text {standard }}\right] \times 1000(\%)
\end{aligned}
$$

The $\delta^{13} \mathrm{C}$ is the ${ }^{13} \mathrm{C} /{ }^{12} \mathrm{C}$ ratio measured by the AMS simultaneously with the ${ }^{14} \mathrm{C}$ measurement.

\subsection{Analysis of radiocesium}

The seawater samples were nondestructively counted directly using high efficiency HPGe spectrometers placed in the in the CAVE (Counting Laboratory for Environmental Radionuclides) underground facility of IAEA-EL (Povinec et al., 2004a, b, 2005b, 2012b). The counting periods were between 24 and 72 hours.

The data quality of radionuclide analyses was assured by regular participation in intercomparison exercises, and by analysis of IAEA (International Atomic Energy Agency) reference materials (Irish Sea water: IAEA-381, Povinec et al., 2002; Mediterranean Sea water: IAEA-418, Pham et al., 2010; and Irish Sea water: IAEA-443, Pham et al., 2011).

\section{Results and discussion}

\subsection{Radiocesium}

The measured ${ }^{137} \mathrm{Cs}$ activity concentrations in surface waters collected 30-600 km offshore the Fukushima NPP ranged from $15 \mathrm{mBq} \mathrm{L}^{-1}$ to $1120 \mathrm{mBq} \mathrm{L}^{-1}$ (Table 1, Fig. 2a). They were by about three orders of magnitude higher than the global fallout background, although the cruise track did not go closer than $30 \mathrm{~km}$ from the coast. Even at distances around $600 \mathrm{~km}$ off Fukushima, ${ }^{137} \mathrm{Cs}$ activity concentrations of around $0.2 \mathrm{~Bq} \mathrm{~L}^{-1}$ were found, i.e. by about a 
factor of 200 above the global fallout background of $1 \mathrm{mBq} \mathrm{L}{ }^{-1}$. The observed elevated ${ }^{137} \mathrm{Cs}$ levels covered an area of around $150000 \mathrm{~km}^{2}$ (south of $38^{\circ} \mathrm{N}$ and west of $147^{\circ} \mathrm{E}$ ).

A considerable decrease in surface ${ }^{137} \mathrm{Cs}$ levels took place between the KoK cruise measurements (3.5 Bq L ${ }^{-1}$, June 2011) and those carried out earlier when about $24 \mathrm{~Bq} \mathrm{~L}^{-1}$ of ${ }^{137} \mathrm{Cs}$ were measured in seawater $30 \mathrm{~km}$ offshore Fukushima (Povinec et al., 2013a). The ${ }^{134} \mathrm{Cs}$ and ${ }^{137} \mathrm{Cs}$ data presented in Table 1 confirms that the ${ }^{134} \mathrm{Cs} /{ }^{137} \mathrm{Cs}$ activity ratio in the analyzed seawater samples was close to 1, clearly indicating that the source of these radionuclides was the Fukushima accident.

Figure 2a clearly separates the western KoK stations with higher ${ }^{137} \mathrm{Cs}$ levels from the eastern stations with smaller activity concentrations. The geographical distribution of ${ }^{137} \mathrm{Cs}$ levels in the water column indicates that an atmospheric deposition of ${ }^{137} \mathrm{Cs}$ occurred within the $600 \mathrm{~km}$ zone offshore Fukushima. For example, the increased ${ }^{3} \mathrm{H},{ }^{134} \mathrm{Cs}$ and ${ }^{137} \mathrm{Cs}$ activities found at St. 8 (Table 1), in agreement with other KoK data (Buesseler et al., 2012), should not be affected by direct liquid releases from the Fukushima NPP, but an atmospheric deposition took place there.

At some stations (e.g., St. 18, 24) subsurface maxima at $50 \mathrm{~m}$ water deth have already been observed three months after the accident (Table 1, Fig. 2a). At other stations (e.g., St. 22, 25 and 26) located closer to the Fukushima coast, the maximum radiocesium leves were observed in surface seawater, especially at St. 25 , where surface ${ }^{137}$ Cs levels exceeded the global fallout values by about three orders of magnitude.

Distribution of ${ }^{137} \mathrm{Cs}$ in the water column of the western North Pacific Ocean was investigated in the framework of the WOMARS (Worldwide Marine Radioactivity Studies) project, carried out by IAEA during 1995-2005 (Livingston and Povinec, 2005; IAEA, 2005; Povinec et al., 2005b, 2010). On the basis of the data stored in the GLOMARD/MARIS database (Povinec et al. 2004b, 2005b, 2006; www.iaea.org/monaco), and taking into account an effective half-life of ${ }^{137} \mathrm{Cs}$ in surface waters of $13 \pm 1$ yr (Povinec et al., 2005b), the background (global fallout) ${ }^{137} \mathrm{Cs}$ level for the western North Pacific Ocean was estimated to be $(1.1 \pm 0.1) \mathrm{mBq} \mathrm{L}^{-1}$. Unfortunately the IAEA'97 station (Fig. 1b) is not in the KoK region (called the Mixed-Water Region or Transition Zone), but it was under influence of the Kuroshio Current (Povinec et al., 2003). However, as we do not have better pre-Fukushima ${ }^{137} \mathrm{Cs}$ profiles we compare in Fig. $2 \mathrm{~b}$ the KoK profiles with the IAEA'97 (St. 1, decay corrected to June 2011) profile. All KoK ${ }^{137} \mathrm{Cs}$ data are well above the IAEA'97 data, confirming thus Fukushima impact on all visited stations. 
Fig. 2 b compares the ${ }^{137} \mathrm{Cs}$ water profiles with other post-Fukushima data (Ramzaev et al. 2014; Kumamoto et al., 2014, 2015; Aoyama et al. 2015a), which were measured in the Transition Zone, however, some of the stations were outside of the KoK region. The highest ${ }^{137}$ Cs levels were measured at the KoK stations (St. 25 and 23) as well as at the UM and KT stations situated closest to the coast. The surface ${ }^{137} \mathrm{Cs}$ levels in the KoK region are mostly between 0.1 and $1 \mathrm{~Bq} \mathrm{~L}^{-1}$, while the levels at other stations are below $0.1 \mathrm{~Bq} \mathrm{~L}^{-1}$. Although the P10 stations (e.g. St. P10-098) are at larger distances from the coast than the RGS stations (e.g. St. 7), their ${ }^{137} \mathrm{Cs}$ levels are higher, indicating possible deposition of ${ }^{137} \mathrm{Cs}$ from radioactive clouds.

The inventory of a radionuclide in a seawater column was calculated by interpolating the radionuclide concentration measured at each depth using the following equation

$$
I_{R}=\frac{1}{2}\left\{\sum_{i=1}^{N}\left(W_{i+1}+W_{i}\right)\left(d_{i+1}-d_{i}\right)+2 W_{1} d_{1}+2 W_{N}\left(d_{B}-d_{N}\right)\right\},
$$

where $I_{R}$ is the inventory of the radionuclide $R$ in the seawater column $\left(\mathrm{Bq} / \mathrm{m}^{2}\right), N$ is the number of sampling depths, $W_{i}$ is the radionuclide concentration in seawater at depth $i, d_{i}$ is the $i$-th sampling depth of seawater, and $d_{B}$ is the total water depth to the bottom. For example the ${ }^{137} \mathrm{Cs}$ inventory calculated for the water column at St. 26 was $(30 \pm 3) \mathrm{kBq} \mathrm{m}^{-2}$. The total inventories were calculated by integrating water column inventories and multiplying them by the corresponding areas.

Our preliminary ${ }^{137} \mathrm{Cs}$ inventory calculated for the KoK region was $(2.2 \pm 0.3) \mathrm{PBq}$ (Povinec et al., 2013d), in reasonable agreement with previous estimation of Buesseler et al. (2012). In the present paper we included all the available ${ }^{137} \mathrm{Cs}$ data measured during 20112012 in the region (Honda et al., 2012; Kaeriyama et al., 2013; Kameník et al., 2013; Ramzaev et al., 2014; Kumamoto et al., 2013a, 2014, 2015; Aoyama et al., 2016a, b), and we got for the total inventory a value of $(2.7 \pm 0.4) \mathrm{PBq}$. This lower value when compared with the recent estimation of the direct liquid release inventory of (3.6 \pm 0.7$) \mathrm{PBq}$ (Aoyama et al., 2015b), may be due to the fact that the investigated region covered only a limited area, 36 $39^{\circ} \mathrm{N}$ and $141.5^{\circ}-148^{\circ} \mathrm{E}$, as well as that part of the direct liquid discharges have already been transported out of the investigated region when seawater samling in 2011-2012 was carried out.

Unfortunately we do not know a pre-Fukushima ${ }^{137} \mathrm{Cs}$ inventory for the investigated region. We may expect, however, that it will be lower than for the western North Pacific due to the presence of Oyashio Intrusion waters in the western part of the Transition Zone (Tatebe 
and Yasuda, 2004; Fig. 1a). Upwelling of deeper waters (with lower radionuclide levels) occurs in the Oyashio region, which are then transported by the Oyashio Intrusion to the western part of the Transition Zone, causing there a dilution of radionuclide levels (including ${ }^{137} \mathrm{Cs}$ ). Our estimation is that the pre-Fukushima ${ }^{137} \mathrm{Cs}$ inventory in the western part of the KoK region should be around $200 \mathrm{~Bq} \mathrm{~m}^{-2}$ (for the top $200 \mathrm{~m}$ of the water column), i.e. by about a factor of two lower than the value estimated for the open western North Pacific Ocean (Aoyama end Hirose, 2004; Povinec et al. 2010). This global fallout background is negligible ( $\sim 0.01 \mathrm{PBq}$ ) when compared with the Fukushima impact on the ${ }^{137} \mathrm{Cs}$ inventory in western North Pacific waters.

\subsection{Tritium}

Tritium levels measured in the KoK samples varied in the range of 0.4-1.3 TU (Table 1), with the maximum at St. 25 (sampled at $10 \mathrm{~m}$ water depth) situated $30 \mathrm{~km}$ off the Fukushima coast (the closest station to the Fukushima NPP, Fig. 1a), where the radiocesium levels were also at their maxima (Table 1). All KoK sampling stations were affected by the Fukushima-derived tritium, the lowest tritium activity $(0.37 \pm 0.02 \mathrm{TU})$ was found at St. 11 at $100 \mathrm{~m}$ water depth. As we already mentioned in the radiocesium section, the western Kok stations were under the influence of the Oyashio Intrusion, which should also dilute tritium concentrations in this region (Figs. 1a and 3).

The tritium seawater profiles (Fig. 3) generally follow the ${ }^{137} \mathrm{Cs}$ water profiles presented in Fig. 2a. The average ${ }^{3} \mathrm{H} /{ }^{137} \mathrm{Cs}$ activity ratio is $0.5 \pm 0.3$ (Table 1 ), with high values at the depth of $100 \mathrm{~m}$ at St. 20, 26 and 25 (2.2, 2.0 and 1.2, respectively), indicating a penetration of tritium into deeper layers of the water column. On the other hand, the lowest ${ }^{3} \mathrm{H} /{ }^{137} \mathrm{Cs}$ activity ratios (0.1-0.3) observed in surface waters (7-20 m) at several stations (e.g., St. 18, 27, 29, 30, 31,32 ) have been confirming the dominance of radiocesium in surface waters. Generally, the observed lower tritium than radiocesium levels may be attributed to lower tritium releases during the Fukushima accident, due to much lower fission yield of ${ }^{3} \mathrm{H}$ compared to ${ }^{137} \mathrm{Cs}$, as well as due to the fact that the boiling water reactors produce much less tritium than the pressurized water reactors.

Although the most comprehensive oceanographic study with the most extensive coverage of ${ }^{3} \mathrm{H}$ in the World Ocean was the WOCE (World Ocean Circulation Experiment, www.eWOCE.org) program conducted in the 1980s and 1990s, there were no sampling stations in the KoK region, which could be compared with our data. Tritium distribution in 
the western North Pacific Ocean was also investigated in the framework of the WOMARS project. The background tritium level for the western North Pacific Ocean can be estimated from the GLOMARD/MARIS database (Povinec et al., 2004b, 2005b) to be $(0.4 \pm 0.1)$ TU (decay corrected to June 2011).

The only available pre-Fukushima tritium profile in the KoK region is from Watanabe et al. (1991), measured in 1988 (Fig. 3, decay corrected to June 2011). Their results are generally lower when compared with the IAEA'97 station (Povinec et al., 2010), although the ${ }^{3} \mathrm{H}$ profiles should be between the GEOSECS (Ostlund et al., 1987) and the IAEA'97 profiles. This may be due to the fact that the Watanabe et al. (1991) station was located in the western Transition Zone (with influence of the Oyashio Intrusion), while the GEOSECS and IAEA stations were in the Subtropical Zone and in the Kuroshio region, respectively (Fig. 1b). Following the Watanabe et al. (1991) profile (Fig. 3), the pre-Fukushima tritium background concentration in surface water of the western KoK region can be as low as $0.2 \mathrm{TU}$, increasing thus the Fukushima impact on tritium levels by about a factor of six.

There was generally agreement between the GEOSECS, IAEA and Watanabe et al. stations regarding the vertical transport of tritium in the water column. A penetration of global fallout ${ }^{3} \mathrm{H}$ down to about $1000 \mathrm{~m}$ depth has been observed, which also predicts the future transport of Fukushima tritium in the water column. The future penetration of Fukushimaderived tritium from surface waters into deeper layers of the ocean will be useful for studying pathways and time scales of deep-water formation (e.g. Povinec et al., 2010, 2011).

The tritum inventory in the water column at St. 26, situated close to the Fukushima coast, calculated using eq. 3 and the water depth profile data is $(17 \pm 2) \mathrm{kBq} \mathrm{m}{ }^{-2}$, which is aproximately half of the ${ }^{137} \mathrm{Cs}$ inventory in the same location, thus leading to the ${ }^{3} \mathrm{H} /{ }^{137} \mathrm{Cs}$ activity ratio of $\sim 0.5$. A preliminary estimation of the total ${ }^{3} \mathrm{H}$ releases to the marine environment was in the range of 0.1-0.5 PBq (Povinec et al., 2013d). From the full set of ${ }^{3} \mathrm{H} /{ }^{137} \mathrm{Cs}$ activity ratios in the water column, and the previously estimated ${ }^{137} \mathrm{Cs}$ releases to the sea, we may estimate the total ${ }^{3} \mathrm{H}$ activity released and deposited offshore of the Fukushima coast to be $(0.3 \pm 2) \mathrm{PBq}$.

Matsumoto et al. (2013) estimated the ${ }^{3} \mathrm{H}$ concentration in the air during an early stage of the accident in March 2011 to be around $1.5 \mathrm{kBq} \mathrm{m}^{-3}$. The ${ }^{3} \mathrm{H}$ levels in precipitation collected at distances 170-220 km from the Fukushima NPP during 21-23 March 2011 were up to 19 $\mathrm{Bq} \mathrm{L}^{-1}$ of water, about 27 times above the pre-Fukushima levels (Matsumoto et al. 2013), but still by a factor of 5 below the EU limit for ${ }^{3} \mathrm{H}$ concentration in drinking water. Similarly, Liu et al. (2013) observed in Taiwan rains during May-December $2011{ }^{3} \mathrm{H}$ levels below $7 \mathrm{~Bq} \mathrm{~L}^{-1}$ 
of water. All these levels have been much lower than the tritium maximum (up to $1180 \mathrm{~Bq} \mathrm{~L}^{-1}$ of water) observed in 1963 in the Northern Hemisphere precipitation after the large-scale atmospheric nuclear bomb tests carried out during 1961 and 1962 (Povinec et al., 2013a).

Measured tritium concentrations and the calculated tritium inventories confirm that the distribution of ${ }^{3} \mathrm{H}$ in the western North Pacific Ocean was influenced by the Fukushima accident. The pre-Fukushima tritium data, e.g. those previously gathered in the framework of the WOCE and WOMARS projects do not represent anymore global fallout distribution of this radionuclide in the western North Pacific Ocean.

\subsection{Radiocarbon}

The observed ${ }^{14} \mathrm{C}$ levels in $\mathrm{KoK}$ water profiles (Fig. 4) show typical features: the concentrations were highest usually at the sub-surface layers (around -20\%o at 100-200 m water depth), and then they decreased down to around $-115 \%$ at $400-500 \mathrm{~m}$ water depth. All $\Delta^{14} \mathrm{C}$ values observed offshore Fukushima were negative, much lower when compared with the IAEA'97 (Aramaki et al., 2001; Povinec et al., 2004c), GEOSEC (Stuiver and Östlund, 1983) and WOCE stations (Key et al. 1996, 2002, 2004). The ${ }^{14} \mathrm{C}$ of global fallout origin observed at these stations penetrated down to about $1000 \mathrm{~m}$ (Stuiver and Ostlund, 1983; Povinec et al., 2004c), similarly as it was observed in the case of ${ }^{3} \mathrm{H}$ (Ostlund et al., 1987; Povinec et al., 2010). The observed decrease in surface $\Delta{ }^{14} \mathrm{C}$ levels after GEOSECS $(\sim 150 \%$ o in 1973; Stuiver and Östlund, 1983) and IAEA'97 ( 90\%o in 1997; Povinec et al., 2004c) would predict $\Delta{ }^{14} \mathrm{C}$ levels in 2011 around 50\%o. However, all the measured $\Delta^{14} \mathrm{C}$ levels in 2011 in the KoK samples were below 0\%, indicating that a comparison with IAEA and GEOSECS stations has not been appropriate because of different position of sampling stations. We have already noticed that ${ }^{3} \mathrm{H}$ levels in the western KoK region were influenced by Oyashio Intrusion, which brought low tritium activity waters to this region. In the case of ${ }^{14} \mathrm{C}$ the situation could be similar as the negative $\Delta{ }^{14} \mathrm{C}$ values were observed at all visited stations, including water profiles at St. 11 and 20 down to $500 \mathrm{~m}$ water depth (Fig. 4). PreFukushima ${ }^{14} \mathrm{C}$ water profiles, measured in the western North Pacific by Tsunogai et al. (1995) and Kumamoto et al. (2002) also showed negative $\Delta^{14} \mathrm{C}$ values (Fig. 4), however, these stations were located in the Oyashio region (Fig. 1b).

Surface ${ }^{14} \mathrm{C}$ concentration in seawater is regulated mainly by the $\mathrm{CO}_{2}$ air - sea exchange, and the residence time of surface water in the region (Kumamoto et al., 2013b). Because of 
506 the upwelling of deeper waters with lower ${ }^{14} \mathrm{C}$ levels in the Oyashio region, and their 507 transport by the Oyashio Intrusion to the western part of the Transition zone, the surface ${ }^{14} \mathrm{C}$ 508 levels in this region are lower than in the Kuroshio region as a mixing of Oyashio and 509 Kuroshio waters occur in the Transition Zone (Kumamoto et al., 2002). All KoK ${ }^{14} \mathrm{C}$ stations 510 located in the western Transition Zone showed negative $\Delta^{14} \mathrm{C}$ values, indicating that these 511 stations were under the influence of the Oyashio Intrusion waters. On the other hand, St. C22 512 and C23 sampled in 1993 by Aramaki et al. (2005) showed positive $\Delta^{14} \mathrm{C}$ values (around $51370 \%$ ), confirming that these stations were outside of the Oyashio Intrusion region (Fig. 1a, b).

514 The data presented in Fig. 4 show that the ${ }^{14} \mathrm{C}$ levels measured in the KoK seawater 515 samples are higher than the pre-Fukushima results measured in the Oyashio region $\left(44^{\circ} 00^{`} \mathrm{~N}\right.$, $516155^{\circ} 00^{\prime} \mathrm{E}$ ) in 1997 by Kumamoto et al. (2002), but comparable with the results of Tsunogai et 517 al. (1995) measured in 1985, also in the Oyashio region $\left(43^{\circ} 00^{\prime} \mathrm{N}, 150^{\circ} 14^{\prime} \mathrm{E}\right)$. As we do not 518 have pre-Fukushima ${ }^{14} \mathrm{C}$ data for the KoK region, we may accept the Kumamoto et al. (2002) 519 surface ${ }^{14} \mathrm{C}$ data as a possible background for the KoK stations (after appropriate residence 520 time corrections between 1997 and 2011). This assumption seems to be reasonable for surface 521 St. 19, 21, 25 and 29 (the average $\Delta^{14} \mathrm{C}$ value beeing -55\%), however, the water profiles at 522 St. 11 and 20 showed at $100 \mathrm{~m}$ and $200 \mathrm{~m}$ water depths increased $\Delta^{14} \mathrm{C}$ values to $-20 \%$, while 523 at water depths of $400 \mathrm{~m}$ and $500 \mathrm{~m}$ they decreased to around $-115 \%$. If we take these deeper 524 values as a possible background (as at the 400-500 m water depth we do not expect a 525 Fukushima impact already in June 2011), the Fukushima contributions to ${ }^{14} \mathrm{C}$ levels in the 526 investigated region can be 6\% and 9\% for surface and 100-200 m water depths, respectively. 527 As the $\mathrm{KoK}{ }^{14} \mathrm{C}$ stations were not located close to the coast, we may expect (similarly as in 528 the case of ${ }^{137} \mathrm{Cs}$ and ${ }^{3} \mathrm{H}$ ) that the Fukushima impact on the ${ }^{14} \mathrm{C}$ levels in the western part of 529 the transition Zone could be even stronger.

530 There are no additional data available on radiocarbon levels in the atmosphere or in 531 seawater after the Fukushima accident. Possible ${ }^{14} \mathrm{C}$ contributions of Fukushima origin were 532 discussed in tree rings of the Japanese cedar grown in Iwaki (Fukushima Prefecture, Xu et al., 533 2015), and in ginkgo leaf samples from Korea (Park et al., 2013). Both samples showed for 5342011 a smaller than expected decrease in ${ }^{14} \mathrm{C}$ from the exponential trend, which may imply a $535{ }^{14} \mathrm{C}$ release during the Fukushima accident.

\section{Conclusions}


539 The analysis of ${ }^{137} \mathrm{Cs},{ }^{3} \mathrm{H}$ and ${ }^{14} \mathrm{C}$ in surface and water column samples collected in the western North Pacific Ocean after the Fukushima accident showed that the Fukushima impact has been mainly on ${ }^{137} \mathrm{Cs}$ in the marine environment. The ${ }^{137} \mathrm{Cs}$ concentrations observed in surface seawater of the western North Pacific Ocean were due to the Fukushima accident higher by about three orders of magnitude. On the other hand the ${ }^{3} \mathrm{H}$ levels were above the global fallout background only by about a factor of 6 . The ${ }^{14} \mathrm{C}$ data suggest that the impact on radiocarbon levels in the western North Pacific Ocean was measurable, but only around 9\% above the background. The water column data indicated that the Fukushima-derived radionuclides already in June 2011 reached depths down to around $200 \mathrm{~m}$.

The ${ }^{137} \mathrm{Cs}$ inventory in the water column of the investigated western North Pacific Ocean affected by the Fukushima accident was estimated to be $(2.7 \pm 0.4) \mathrm{PBq}$, which can be regarded as a lower limit of the direct ${ }^{137} \mathrm{Cs}$ liquid discharges to the ocean. This lower value when compared with the recent estimation of the direct liquid release inventory of $(3.6 \pm 0.7)$ PBq (Aoyama et al., 2016b) may be due to the fact that the region under study did not cover the full area affected by the Fukushima liquid releases. On the basis of ${ }^{3} \mathrm{H} /{ }^{137} \mathrm{Cs}$ activity ratios in the water column profiles, the total ${ }^{3} \mathrm{H}$ inventory was estimated to be $(0.3 \pm 0.2) \mathrm{PBq}$.

Measured tritium and radiocarbon concentrations in the western North Pacific Ocean confirm that their distribution has been influenced by the Fukushima accident. The preFukushima tritium and radiocarbon data, e.g. those previously gathered in the framework of the WOCE and WOMARS projects, do not represent anymore the global fallout distribution of these radionuclide in the western North Pacific Ocean.

Further studies of these radionuclides in the water column of the North Pacific Ocean are necessary for better estimation of the atmospheric input (via a wet and dry deposition) to their total inventory. The investigated radionuclides will be useful tracers during the next decades for studying pathways, ocean currents and time scales of deep and bottom water formation, for studying biogeochemical processes in the water column, circulation of water masses in the North Pacific Ocean, and transport of North Pacific waters to the South Pacific and the Indian Oceans.

\section{Acknowledgments}

The authors are thankful to Dr. S. Sheppard (Chief Editor of JER) for useful comments, and to prof. K. Hirose and dr. Y. Kumamoto for recent radiocesium data for the western North Pacific Ocean. We also thank Dr. K. O. Buesseler for provision of seawater samples collected during the $\mathrm{A} / \mathrm{V}$ Ka'imikai-o-Kanaloa $(\mathrm{KoK})$ cruise in the western North Pacific 
Ocean, the Gordon and Betty Moore Foundation, and the Chemical Oceanography Program of the US National Science Foundation for funding the KoK expedition. The Bratislava group acknowledges a support provided by the EU Research and Development Operational Program (funded by the ERDF, Project No. 26240220004). The International Atomic Energy Agency is grateful to the Government of the Principality of Monaco for support provided to its Environment Laboratories.

\section{References}

Aarkrog, A., Baxter, M.S., Bettencourt, A.O., Bojanowski, R., Bologa, A., Charmasson, S., Cunha, I., Delfanti, R., Duran, E., Holm, E., Jeffree, R., Livingston, H.D., Mahapanyawong, S., Nies, H., Osvath, I., Pingyu, L., Povinec, P.P., Sanchez, A., Smith, J.N., Swift, D., 1997. A comparison of doses from ${ }^{137} \mathrm{Cs}$ and ${ }^{210} \mathrm{Po}$ in marine food: A major international study. J. Environ. Radioact. 34, 69-90.

Aoyama, M., Hirose, K., 2004. Artificial radionuclides database in the Pacific Ocean: HAM database. ScientificWorldJournal 4:200-215.

Aoyama, M., Tsumune, D., Hamajima, Y., 2012a. Distribution of ${ }^{137} \mathrm{Cs}$ and ${ }^{134} \mathrm{Cs}$ in the North Pacific Ocean: impacts of the TEPCO Fukushima-Daiichi NPP accident. J. Radioanal. Nucl. Chem. 296, 535-539.

Aoyama, M., Tsumune, D., Uematsu, M., Kondo, F., Hamajima, Y., 2012b. Temporal variation of ${ }^{134} \mathrm{Cs}$ and $137 \mathrm{Cs}$ activities in surface water at stations along the coastline near the Fukushima Dai-ichi Nuclear Power Plant accident site, Japan. Geochem. J. 46, 321325.

Aoyama, M., Uematsu, M., Tsumune, D., Hamajima, Y., 2013. Surface pathway of radioactive plume of TEPCO Fukushima NPP1 released ${ }^{134} \mathrm{Cs}$ And ${ }^{137} \mathrm{Cs}$. Biogeosciences, 10, 3067-3078.

Aoyama, M., Hamajima, Y., Hult, M., Uematsu, M., 2016a. ${ }^{134} \mathrm{Cs}$ and ${ }^{137} \mathrm{Cs}$ in the North Pacific Ocean derived from the March 2011 TEPCO Fukushima Dai-ichi Nuclear Power Plant accident, Japan. Part one: surface pathway and vertical distributions. J. Oceanography 72, 53-65.

Aoyama, M., Kajino, M., Tanaka, T.Y., Sekiyama, T.T., Tsumune, D., Tsubono, T., Hamajima, Y., Inomata, Y., Gamo, T., 2016b. ${ }^{134} \mathrm{Cs}$ and ${ }^{137} \mathrm{Cs}$ in the North Pacific Ocean derived from the TEPCO Fukushima Dai- ichi Nuclear Power Plant accident, Japan in March 2011: Part Two - Estimation of ${ }^{134} \mathrm{Cs}$ and ${ }^{137}$ Cs inventories in the North Pacific Ocean. J. Oceanography 72, 67-76.

Aramaki, T., Mizushima, T., Kuji, T., Povinec, P.P., Togawa, O., 2001. Distribution of radiocarbon in the southwestern North Pacific. Radiocarbon 43, 857-867.

Aramaki, T., Togawa, O., Watanabe, S., Tsunogai, S., Taira, K., 2005. Temporal change of radiocarbon in the Western North Pacific. JAERI Report, Mutsu.

Buesseler, K.O., Jayne, S.R., Fisher, N.S., Rypina, I.I., Baumann, H., Baumann, Z., Breier, C. F., Douglass, E.M., George, J., Macdonald, A.M., Miyamoto, H., Nishikawa, J., Pike, S. 
M., Yoshida, S., 2012. Fukushima-derived radionuclides in the ocean and biota off Japan. Proc. Nat. Acad. Sci. USA 109, 5984-5988.

Buzinny, M., Likhtarev, I., Los, I., Talerko, N., Tsigankov, N., 1998. ${ }^{14} \mathrm{C}$ analysis of annual tree rings from the vicinity of the Chernobyl NPP. Radiocarbon 40, 373-379.

Chino, M., Nakayama, H., Nagai, H., Terada, H., Katata, G., Yamazawa, H., 2011. Preliminary estimation of release amounts of ${ }^{131} \mathrm{I}$ and ${ }^{137} \mathrm{Cs}$ accidentally discharged from the Fukushima Daiichi nuclear power plant into the atmosphere. J. Nucl. Sci. Technol., 48, 1129-1134.

Chudý M., Povinec P., 1982. Radiocarbon production in CO2 coolant of nuclear reactor. Acta Physica Univ. Comen. 22, 127-131.

Dietze, H., Kriest, I. 2012. ${ }^{137}$ Cs off Fukushima Dai-ichi, Japan: model based estimates of dilution and fate. Ocean Sci. 8, 319-332.

Estournel, C., Bosc, E., Bocquet, M., Ulses, C., Marsaleix, P., Winiarek, V., Osvath, I., Nguyen, C., Duhaut, T., Lyard, F., Michaud, H., Auclair, F., 2012. Assessment of the amount of Cesium-137 released into the Pacific Ocean after the Fukushima accident and analysis of its dispersion in Japanese coastal waters. J. Geophys. Res. 117, C11014. http://dx.doi.org/10.1029/2012JC007933.

Hernández-Ceballos, M.A., Hong, G.H., Lozano, R.L., Kim, Y.I., Lee, H.M., Kim, S.H., Yeh, S.W., Bolívar, J.P., Baskaran, M., 2012. Tracking the complete revolution of surface westerlies over Northern Hemisphere using radionuclides emitted from Fukushima, Sci. Total Environ. 438, 80-85.

Hirose, K., 2012. 2011 Fukushima Dai-ichi nuclear power plant accident: summary of regional radioactive deposition monitoring results. J. Environ. Radioact. 111, 13-17.

Honda, M., Aono, T., Aoyama, M., Hamajima, Y., Kawakami, H., Kitamura, M., Masumoto, Y., Miyazawa, Y., Takigawa, M., Saino, T., 2012 Dispersion of artificial caesium-134 and -137 in the Western North Pacific one month after the Fukushima accident. Geochem. J. 46, 1-9.

Hou, X.L., Povinec, P.P., Zhang, L. Y., Biddulph, D., Chang, C.-C., Fan, Y.K., Golser, R., Ješkovský, M., Jull, A.J.T., Liu, Q., Shi, K. L., Steier, P., Zhou, W.J., 2013. Iodine-129 in seawater offshore Fukushima: Distribution, speciation, sources, and budget. Environ. Sci. Technol. 47, 3091-3098.

IAEA, 2005. Worldwide marine radioactivity studies (WOMARS). Radionuclide levels in oceans and sea. IAEA-TECDOC-1429, Vienna, Austria.

Inoue, M., Kofuji, H., Nagao, S., Yamamoto, M., Hamajima, Y., Yoshida, K., Fujimoto, K., Takada, T., Isoda, Y., 2012, Lateral variation of ${ }^{134} \mathrm{Cs}$ and ${ }^{137} \mathrm{Cs}$ concentrations in surface seawater in and around the Japan Sea after the Fukushima Dai-ichi Nuclear Power Plant accident. J. Environ. Radioact. 109, 45-51.

Jean-Baptiste, P., Fourré, E., Dapoigny, A., Baumier, D., Baglan, N., Alanic, G., 2010. ${ }^{3} \mathrm{He}$ mass spectrometry of very low-level measurement of organic tritium in environment samples J. Environ. Radioact. 101, 185-189.

Kaeriyama, H., Ambe, D., Shimizu, Y., Fujimoto, K., Ono, T., Yonezaki, S., Kato, Y., Matsunaga, H., Minami, H., Nakatsuka, S., Watanabe, T. Direct observation of ${ }^{134} \mathrm{Cs}$ and 
${ }^{137} \mathrm{Cs}$ in surface seawater in the western and central North Pacific after the Fukushima Daiichi nuclear power plant accident (2013) Biogeosciences, 10 (6), pp. 4287-4295.

Kameník, J., Dulaiova, H., Buesseler, K.O., Pike S.M., Št’astná, K., 2013. Cesium-134 and 137 activities in the central North Pacific Ocean after the Fukushima Dai-ichi Nuclear Power Plant accident. Biogeosciences 10, 6045-6052.

Kawamura, H., Kobayashi, T., Furuno, A., In, T., Ishikawa, Y., Nakayama, T., Shima, S., Awaji, T., 2011. Preliminary numerical experiments on oceanic dispersion ${ }^{131} \mathrm{I}$ and ${ }^{137} \mathrm{Cs}$ discharged into the ocean because of the Fukushima Dai-ichi nuclear power plant disaster. J. Nucl. Sci. Technol. 48, 1349-1356.

Key, R., Quay, P., Jones, G., McNichol, A., von Reden, K., Schneider, R., 1996. WOCE AMS radiocarbon I: Pacific Ocean results (P6, P16 and P17). Radiocarbon 38, 425-518.

Key, R., Quay, P., Schlosser, P., McNichol, A., von Reden, K., Schneider, R., Elder, K., Stuiver, M., Ostlund, H., 2002. WOCE radiocarbon IV: Pacific Ocean results; P10, P13N, P14C, P18, P19 \& S4P. Radiocarbon 44, 239-392.

Key, R.M., Kozyr, A., Sabine, C.L., Lee, K., Wanninkhof, R., Bullister, J.L., Feely, R.A., Millero, F.J., Mordy, C., Peng, T.-H., 2004. A global ocean carbon climatology: Results from Global Data Analysis Project (GLODAP). Global Biogeochem. Cy. 18(4), GB4031. http://dx.doi.org/10.1029/2004GB002247.

Kim, H.G., Kong, T.Y., Lee, G.J., Jeong, W.T., Kim, S.T., 2011. Analysis of metabolism and effective half-life for radiation workers' tritium intake at pressurized heavy water reactors. Progress Nucl. Sci. Technol. 1, 545-548.

Kirchner, G., Bossew, P., De Cort, M., 2012. Radioacitvity from Fukushima Dai-ich in air over Europe; part 2: what can it tell us about the accident? J. Environ. Radioact. 114, 3540. http://dx.doi.org/10.1016/j.jenvrad.2011.12.016.

Kumamoto, Y., Murata, A., Saito, C., Honda, M., Kusakabe, M., 2002. Bomb radiocarbon invasion into the northwestern North Pacific. Deep Sea Res. II 49, 5339-5351.

Kumamoto, Y., Murata, A., Kawano, T., Aoyama, M., 2013a. Fukushima-derived radiocesium in the northwestern Pacific Ocean in February 2012. Appl. Radiat. Isotopes 81, 335-339.

Kumamoto, Y., Murata, A., Kawano, T., Watanabe, S., Fukasawa, M., 2013b. Decadal changes in bomb-produced radiocarbon in the Pacific Ocean from the 1990s to 2000s. Radiocarbon 55, 1641-1650.

Kumamoto, Y., Aoyama, M., Hamajima, Y., Aono, T., Kouketsu, S., Murata, A., Kawano, T., 2014. Southward spreading of the Fukushima-derived radiocesium across the Kuroshio Extension in the North Pacific. Sci. Rep. 4, 4276. http://dx.doi.org/10.1038/srep04276.

Kumamoto. Y., Aoyama, M., Hamajima, Y., Murata, A., Kawano, T., 2015. Impact of Fukushima-derived radiocesium in the western North Pacific Ocean about ten months after the Fukushima Dai-ichi nuclear power plant accident. J. Environ. Radioact. 140, 114-122.

Livingston, H.D., Povinec, P.P., 2000. Anthropogenic marine radioactivity. Ocean and Coastal Management 43, 689-712.

Livingston, H.D., Povinec, P.P., 2002. A millennium perspective on the contribution of global fallout radionuclides to ocean science. Health Phys. 82, 656-668. 
Masson, O., Baeza, A., Bieringer, J., Brudecki, K., Bucci, S., Cappai, M., Carvalho, F.P., Connan, O., Cosma, C., Dalheimer, A. Didier, D., Depuydt, G., De Geer, L.E., De Vismes, A., Gini, L., Groppi, F., Gudnason, K., Gurriaran, R., Hainz, D., Halldorsson, O., Hammond, D., Hanley, O. Holey, K. Homoki, Zs., Ioannidou, A. , Isajenko, K., Jankovick M., Katzlberger, C., Kettunen, M., Kierepko, R., Kontro, R. Kwakman, P.J.M., Lecomte, M. , Leon Vintro, L. Leppänen, A.- P., Lind, B., Lujaniene, G., Mc Ginnity, P., Mc Mahon, C., Mala H., Manenti, S., Manolopoulou, M., Mattila, A., Mauring, A., Mietelski, J.W., Møller, B.S., Nielsen, P., Nikolick J., Overwater, R.M.W., Palsson, S. E., Papastefanou, C., Penev, I., Pham, M.K., Povinec, P.P., Ramebäck, H., Reis, M.C. , Ringer, W., Rodriguez, A., Rulík, P., Saey, P.R.J., Samsonov, V., Schlosser, C., Sgorbati, G. , Silobritiene, B. V., Söderström, C., Sogni, R., Solier, L., Sonck, M., Steinhauser, G., Steinkopff, T. , Steinmann, P., Stoulos, S., Sykora, I., Todorovic, D., Tooloutalaie, N., Tositti, L., Tschiersch, J., Ugron, A., Vagena, E., Vargas, A., Wershofen, H., Zhukova O., 2011. Tracking of airborne radionuclides from the damaged Fukushima Dai-Ichi nuclear reactors by European networks. Environ. Sci. Technol. 45, 7670-7677.

Matsumoto, T., Maruoka, T., Shimoda, G., Obata, H., Kagi, H., Suzuki, K.; Yamamoto, K., Mitsuguchi, T., Hagino, K., Tomioka, N., Sambandam, C., Brummer, D., Klaus, P.M., Aggarwal, P., 2013. Tritium in Japanese precipitation following the March 2011 Fukushima Daiichi nuclear plant accident. Sci. Total Environ. 445-446, 365-370.

Miyazawa, Y., Masumoto, Y., Varlamov, S. M., Miyama, T., 2012a. Transport simulation of the radionuclide from the shelf to open ocean around Fukushima. Continental Shelf Res. 50-51, 16-29.

Molnár, M., Hajdas, I., Janovics, R., Rinyu, L., Synal, H., Veres, M., Wacker, L., 2013a. C-14 analysis of groundwater down to the milliliter level. Nucl. Instrum. Meth. Phys. Res. B 294, 573-576.

Molnár, M., Janovics, R., Major, I., Orsovszki, J., Gönczi, R., Veres, M., Leonard, A.G., Castle, S.M., Lange, T.E., Wacker, L., Hajdas, I., Jull, A.J.T., 2013b. Status report of the new AMS 14C sample preparation lab of the Hertelendi Laboratory of Environmental Studies (Debrecen, Hungary). Radiocarbon 55, 665-676.

Morino, Y., Ohara, T., and Nishizawa, M., 2011. Atmospheric behavior, deposition, and budget of radioactive materials from the Fukushima Daiichi nuclear power plant in March 2011. Geophys. Res. Lett. 38, L00G11. http://dx.doi.org/10.1029/2011GL048689.

Nakano, M., Povinec, P.P., 2003. Oceanic general circulation model for the assessment of the distribution of ${ }^{137} \mathrm{Cs}$ in the world ocean. Deep-sea Res. II 50, 2803-2816.

Nakano, M., Povinec, P.P., 2012. Long-term simulations of the ${ }^{137}$ Cs dispersion from the Fukushima accident in the world ocean. J. Environ. Radioact. 111, 109-115.

Nishihara, K., Yamagishi, I., Yasuda, K., Ishimori, K., Tanaka, K., Kuno, T., Inada, S., Gotoh, Y., 2012. Radionuclide release to stagnant water in Fukushima-1 Nuclear Power Plant. Transactions of the Atomic Energy Society of Japan 11, 13-19.

Ostlund, G.H., Craig, H., Broecker, W.B., Spencer, D., 1987. GEOSECS Atlantic, Pacific and Indian ocean expeditions, vol.7, Shorebased data and graphics, National Science Foundation, Washington, D.C., 200 pp. 
Palcsu, L., Major, Z., Köllő, Z., Papp, L., 2010.Using an ultrapure ${ }^{4}$ He spike in tritium measurements of environmental water samples by the ${ }^{3} \mathrm{He}$-ingrowth method. Rapid Comm. Mass Spectr. 24, 698-704.

Park, J.H., Hong, W. Park, G. Sung, K.S., Lee, K.H., Kim, Y.E., Kim, J.K., Choi, H.W., Kim, G.D., Woo, H.J., Nakanishi, T., 2013. A comparison of distribution mapas of $\Delta^{14} \mathrm{C}$ in 2010 and 2011 in Korea. Radiocarbon 55, 841-847.

Pham, M. K., Betti, M., Povinec, P. P., Alfimov, V., Biddulph, D., Gastaud, J., Kieser, W. E., Lopez Gutierez J. M., Possnert, G., Sanchez-Cabeza, J. A., Suzuki, T., 2010. Certified reference material IAEA-418: ${ }^{129}$ I in Mediterranean Sea water. J. Radioanal. Nucl. Chem. 286, 121-127.

Pham, M.K., Betti, M., Povinec, P.P., Benmansour, M., Bünger, V., Drefvelin, J., Engeler, C., Flemal, J.M., Gasco',C., Guillevic, J., Gurriaran, R., Groening, M., Happel, J.D., Herrmann, J., Klemola, S., Kloster, M., Kanisch, G., Leonard, K., Long, S., Nielsen, S., Oh, J.-S., Rieth, P.U., Östergren, I., Pettersson, H., Pinhao, N., Pujol, L., Sato, K., Schikowski, J., Varga, Z., Vartti, V.P., Zheng, J., 2011. A certified reference material for radionuclides in the water sample from Irish Sea (IAEA-443). J. Radioanal. Nucl. Chem. 288, 603-611.

Povinec, P., Chudý, M., Sýkora, I., Szarka, J., Pikna, M., Holý, K., 1988. Aerosol radioactivity monitoring in Bratislava following the Chernobyl accident. J. Radioanal. Nucl. Chem. Lett. 126, 467-478.

Povinec, P.P., Oregioni, B., Jull, A.J.T., Kieser, W.E., Zhao, X.-L., 2000. AMS measurements of ${ }^{14} \mathrm{C}$ and ${ }^{129} \mathrm{I}$ in seawater around radioactive waste dump sites. Nucl. Instrum. Methods Phys. Res. B 172, 672-678.

Povinec, P.P., Badie, C., Baeza, A., Barci-Funel, G., Bergan, T.D., Bojanowski, R., Burnett, W., Eikenberg, J., Fifield, L.K., Serradell, V., Gastaud, J., Goroncy, I., Herrmann, J., Hotchkis, M.A.C., Ikaheimonen, T.K., Jakobson, E., Kalimbadjan, J., La Rosa, J.J., Lee, S-H., Liong Wee Kwong, L., Lueng, W.M., Nielsen, S.P., Noureddine, A., Pham, M.K., Rohou, J-N., Sanchez-Cabeza, J.A., Suomela, J., Suplinska, M., Wyse, E., 2002. Certified reference material for radionuclides in seawater IAEA-381 (Irish Sea water). J. Radioanal. Nucl. Chem. 251, 369-374.

Povinec, P.P., Livingston, H.D., Shima, S., Aoyama, M., Gastaud, J., Goroncy, I., Hirose, K., Huyhn-Ngoc, L., Ikeuchi, Y., Ito, T., La Rosa, J., Liong Wee Kwong, L., Lee, S.-H., Moriya H., Mulsow, S., Oregioni, B., Pettersson, H., Togawa, O., 2003. IAEA'97 expedition to the NW Pacific Ocean - results of oceanographic and radionuclide investigations of the water column. Deep-Sea Res. II 50, 2607-2638.

Povinec, P.P., 2004a. Developments in analytical technologies for marine radioactivity studies. In: H.D. Livingston (Ed.) Marine Radioactivity. Elsevier, Amsterdam, 237-294.

Povinec, P.P., Comanducci, J.F., Levy-Palomo, I., 2004b. IAEA-MEL's underground counting laboratory in Monaco - background characteristics of HPGe detectors with anticosmic shielding. Appl. Rad. Isotopes 61, 85-93.

Povinec, P.P., K. Hirose, T. Honda, T. Ito, E.M. Scott, Togawa, O., 2004b. Spatial distribution of ${ }^{3} \mathrm{H},{ }^{90} \mathrm{Sr},{ }^{137} \mathrm{Cs}$ and ${ }^{239,240} \mathrm{Pu}$ in surface waters of the Pacific and Indian Oceans - GLOMARD database. J. Environ. Radioact. 76, 113-137. 
Povinec, P.P., Aramaki, T., Burr, G.S., Jull, A.J.T., Liong Wee Kwong, L., Togawa, O., 2004c. Radiocarbon in the water column of the southwestern North Pacific Ocean -24 years after GEOSECS. Radiocarbon 46, 583-594.

Povinec, P.P., Comanducci, J.F., Levy-Palomo, I., 2005a. IAEA-MEL's underground counting laboratory (CAVE) for the analysis of radionuclides in the environment at very low-levels. J. Radioanal. Nucl. Chem. 263, 441-445.

Povinec, P. P., Aarkrog, A., Buesseler, K.O., Delfanti, R., Hirose, K., Hong, G.H., Ito, T., Livingston, H.D., Nies, H., Noshkin, V.E., Shima, S., Togawa, O., 2005b. ${ }^{90} \mathrm{Sr},{ }^{137} \mathrm{Cs}$ and ${ }^{239,240} \mathrm{Pu}$ concentration surface water time series in the Pacific and Indian Oceans WOMARS results. J. Environ. Radioact. 81, 63-87.

Povinec, P.P., Scotto, P., Osvath, I., Ramadan, H. 2006. The Marine Information System (MARIS). In: Isotopes in Environmental Studies. IAEA, Vienna, 68-69.

Povinec, P. P., Lee, S. H., Liong Wee Kwong, L.,Oregioni, B., Jull, A. J. T., Kieser, W. E., Morgenstern, U., Top, Z., 2010. Tritium, radiocarbon, ${ }^{90} \mathrm{Sr}$ and ${ }^{129} \mathrm{I}$ in the Pacific and Indian Oceans. Nucl. Instrum. Methods Phys. Res. B 268, 1214-1218.

Povinec, P.P., Breier, R., Coppola, L., Groening, M., Jeandel, C., Jull, A.J.T., Kieser, W.E., Top, Z., 2011. Tracing of water masses using a multi-isotope approach in the southern Indian Ocean. Earth Planetary Sci. Lett. 302, 14-26.

Povinec, P.P., Hirose, K., Aoyama, M., 2012a. Radiostronium in the western North Pacific: Characteristics, behavior, and the Fukushima impact. Environ. Sci. Technol. 46, 1035610363.

Povinec, P. P., Eriksson, M., Scholten, J., Betti, M., 2012b. Marine Radioactivity Analysis. In: M.F. L'Annunziata (Ed.) Handbook on Radioactivity Analysis. Academic Press, Amsterdam, 770-832.

Povinec, P.P., Hirose, K., Aoyama, M., 2013a. Fukushima Accident: Radioactivity Impact on the Environment. Elsevier, New York, 382 pp.

Povinec, P.P., Gera, M., Hirose, K., Lujaniené G., Nakano, M., Plastino, W., 2013b. Dispersion of Fukushima radionuclides in the global atmosphere and the ocean. Appl. Rad. Isotopes 81, 383-392.

Povinec, P.P., Sýkora, I., Gera, M., Holý, K., Brestákova, L., Kováčik, A., 2013c. Fukushima-derived radionuclides in ground-level air of Central Europe: a comparison with simulated forward and backward trajectories. J Radioanal Nucl Chem 295, 11711176. http://dx.doi.org/10.1007/s10967-012-1943-3.

Povinec, P.P., Aoyama, M., Biddulph, D., Breier, R., Buesseler K., Chang, C.C., Golser, R., Hou, X.L., Ješkovský, M., Jull, A.J.T., Kaizer, J., Nakano, M., Nies, H., Palcsu, L., Papp, L., Pham, M.K., 10, Steier, P., Zhang, L.Y., 2013d. Cesium, iodine and tritium in NW Pacific waters - a comparison of the Fukushima impact with global fallout. Biogeosciences 10, 5481-5496.

Povinec, P.P., Ženišová, Z., Šivo, A., Ogrinc, N., Richtáriková, M., Breier, R., 2013e. Radiocarbon and stable isotopes as groundwater tracers in the Danube river basin of SW Slovakia. Radiocarbon 55, 1017-1028.

Povinec, P.P., Hirose, K., 2015. Fukushima radionuclides in the NW Pacific, and assessment of doses for Japanese and world population from ingestion of seafood. Sci. Rep. 5, 9016. http://dx.doi.org/10.1038/srep09016. 
Ramzaev, V., Nikitin, A., Sevastyanov, A., Artemiev, G., Bruk, G., Ivanov, S., 2014. Shipboard determination of radiocesium in seawater after the Fukushima accident: Results from the 2011-2012 Russian expeditions to the Sea of Japan and western North Pacific Ocean. J. Environ. Radioact. 135, 13-24.

Rinyu, L., Molnár, M., Major, I., Nagy, T., Veres, M., Kimák, Á., Wacker, L., Synal, H.A., 2013. Optimization of sealed tube graphitization method for environmental C-14 studies using MICADAS. Nucl. Instrum. Meth. Phys. Res. B 294, 270-275.

Rypina, I.I., Jayne, S.R., Yoshida, S., Macdonald, A.M., Douglass, E., Buesseler, K., 2013. Short-term dispersal of Fukushima-derived radionuclides off Japan: modeling efforts and model-data intercomparison. Biogeosciences 10, 4973-4990. http://dx.doi.org/10.5194/bg-10-4973-2013, 2013.

Steinhauser, G., 2014. Fukushima's Forgotten Radionuclides: A Review of the Understudied Radioactive Emissions. Environ. Sci. Technol. 48, 4649-4663.

Stohl, A., Seibert, P., Wotawa, G., Arnold, D., Burkhart, J. F., Eckhardt, S., Tapia, C., Vargas, A., Yasunari, T. J., 2012. Xenon-133 and caesium-137 releases into the atmosphere from the Fukushima Dai-ichi nuclear power plant: determination of the source term, atmospheric dispersion, and deposition. Atmos. Chem. Phys. 12, 23132343.

Stuiver, M., Ostlund, H.G., 1983. GEOSECS Indian and Mediterranean radiocarbon. Radiocarbon 25, 1-29.

Schwantes, J.M., Orton, C.R., Clark, R.A., 2012. Analysis of a nuclear accident: fission and activation product releases from the Fukushima Daiichi Nuclear Facility as remote indicators of source identification, extent of release, and state of damaged spent nuclear fuel. Environ. Sci. Technol. 46, 8621-8627.

Tatebe, H., Yasuda, I., 2004. Oyashio Southward Intrusion and Cross-Gyre Transport Related to Diapycnal Upwelling in the Okhotsk Sea. J. Phys. Oceanogr. 34, 2327-2341.

Tsumune, D., Tsubono, T., Aoyama, M., Hirose, K., 2012. Distribution of oceanic ${ }^{137}$ Cs from the Fukushima Dai-ichi Nuclear Power Plant simulated numerically by a regional ocean model. J. Environ. Radioact. 111, 100-108.

Tsumune, D., Tsubono, T., Aoyama, M., Uematsu, M., Misumi, K., Maeda, Y., Yoshida, Y., Hayami, H., 2013. One-year, regional-scale simulation of ${ }^{137} \mathrm{Cs}$ radioactivity in the ocean following the Fukushima Daiichi Nuclear Power Plant accident. Biogeosciences 10, 5601-5617.

Tsunogai, S., Watanabe, S., Honda, M., Aramaki, T., 1995. North Pacific Intermediate Water studied chiefly with radiocarbon. J. Oceanogr. 51, 519-536.

UNSCEAR, 2008. United Nations Scientific Committee on the Effects of Atomic Radiation: Sources and Effects of Ionizing Radiation. Report to the General Assembly. United Nations, New York, USA.

Watanabe, Y.W., Watanabe, S., Tsunogai, S., 1991. Tritium in the northwestern North Pacific. Journal of the Oceanographical Society of Japan 47 (3), 80-93.

Xu, S., Cook, G.T., Cresswell, A.J., Dunbar, E., Freeman, S.P.H.T., Hastie, H., Hou, X., Jacobsson, P., Naysmith, P., Sanderson, D.C.W., 2015. Radiocarbon concentration in modern tree rings from Fukushima, Japan. J. Environ. Radioact. 146, 67-72. 
871 Yoshida, N., Kanda, J., 2012. Tracking the Fukushima Radionuclides. Science 336, 1115$872 \quad 1116$.

873

874 
876 Table 1

877 Tritium, radiocarbon and radiocesium in seawater samples collected offshore Fukushima during the

878 KoK cruise.

879

\begin{tabular}{|c|c|c|c|c|c|c|c|}
\hline $\begin{array}{l}\text { Station } \\
\text { number }\end{array}$ & $\begin{array}{l}\text { Position of the } \\
\text { sampling } \\
\text { station }\end{array}$ & $\begin{array}{l}\text { Water } \\
\text { depth } \\
\text { (m) }\end{array}$ & $\begin{array}{l}{ }^{3} \mathrm{H} \\
\text { (TU) }\end{array}$ & $\begin{array}{l}\Delta^{14} C \\
(\%)\end{array}$ & $\begin{array}{l}{ }^{134} \mathrm{Cs} \\
\left(\mathrm{Bq} \mathrm{L} \mathrm{L}^{-1}\right)\end{array}$ & $\begin{array}{l}{ }^{137} \mathrm{Cs} \\
\left(\mathrm{Bq} \mathrm{L} \mathrm{L}^{-1}\right)\end{array}$ & ${ }^{3} \mathrm{H} /{ }^{137} \mathrm{Cs}$ \\
\hline \multirow[t]{2}{*}{2} & $\begin{array}{l}34^{\circ} 30^{\prime} \mathrm{N} \\
147^{\circ} 00^{\prime} \mathrm{E}\end{array}$ & 100 & & & $0.029 \pm 0.009$ & $0.027 \pm 0.009$ & \\
\hline & & 200 & & & $0.016 \pm 0.006$ & $0.015 \pm 0.006$ & \\
\hline 6 & $\begin{array}{l}36^{\circ} 30^{\prime} \mathrm{N} \\
147^{\circ} 00^{\prime} \mathrm{E}\end{array}$ & 20 & & & & $0.026 \pm 0.009$ & \\
\hline \multirow[t]{4}{*}{8} & $\begin{array}{l}37^{\circ} 30^{\prime} \mathrm{N} \\
147^{\circ} 00^{\prime} \mathrm{E}\end{array}$ & 5 & $0.90 \pm 0.06$ & & & & \\
\hline & & 20 & & & $0.178 \pm 0.009$ & $0.184 \pm 0.010$ & \\
\hline & & 50 & & & $0.160 \pm 0.012$ & $0.158 \pm 0.014$ & \\
\hline & & 100 & & & $0.059 \pm 0.006$ & $0.051 \pm 0.007$ & \\
\hline \multirow[t]{6}{*}{11} & $\begin{array}{l}37^{\circ} 30^{\prime} \mathrm{N} \\
144^{\circ} 00^{\prime} \mathrm{E}\end{array}$ & 20 & & & $0.085 \pm 0.008$ & $0.072 \pm 0.009$ & \\
\hline & & 50 & & & $0.105 \pm 0.011$ & $0.080 \pm 0.009$ & \\
\hline & & 100 & $0.37 \pm 0.02$ & $-19.5 \pm 2.9$ & $0.018 \pm 0.009$ & $0.037 \pm 0.009$ & $1.18 \pm 0.03$ \\
\hline & & 200 & & $-10.4 \pm 2.6$ & & & \\
\hline & & 400 & & $-89.9 \pm 3.2$ & & & \\
\hline & & 500 & & $-113.4 \pm 3.0$ & & & \\
\hline \multirow[t]{3}{*}{18} & $\begin{array}{l}37^{\circ} 00^{\prime} \mathrm{N} \\
143^{\circ} 00^{\prime} \mathrm{E}\end{array}$ & 20 & $0.74 \pm 0.055$ & & $0.234 \pm 0.017$ & $0.252 \pm 0.021$ & $0.35 \pm 0.03$ \\
\hline & & 50 & & & $0.426 \pm 0.029$ & $0.425 \pm 0.031$ & \\
\hline & & 100 & & & $0.048 \pm 0.009$ & $0.035 \pm 0.009$ & \\
\hline \multirow[t]{2}{*}{19} & $\begin{array}{l}37^{\circ} 33^{\prime} \mathrm{N} \\
142^{\circ} 57^{\prime} \mathrm{E}\end{array}$ & 5 & & $-61.5 \pm 3.0$ & & & \\
\hline & & 20 & & & $0.188 \pm 0.014$ & $0.171 \pm 0.016$ & \\
\hline \multirow[t]{5}{*}{20} & $\begin{array}{l}38^{\circ} 00^{\prime} \mathrm{N} \\
143^{\circ} 00^{\prime} \mathrm{E}\end{array}$ & 5 & $1.05 \pm 0.05$ & & & & \\
\hline & & 100 & $0.74 \pm 0.05$ & $-21.0 \pm 3.5$ & $0.023 \pm 0.005$ & $0.039 \pm 0.009$ & $2.24 \pm 0.2$ \\
\hline & & 200 & & $-20.5 \pm 3.0$ & $0.015 \pm 0.005$ & $0.019 \pm 0.007$ & \\
\hline & & 400 & & $-102.3 \pm 3.5$ & & & \\
\hline & & 500 & & $-116.8 \pm 2.9$ & & & \\
\hline \multirow[t]{3}{*}{21} & $\begin{array}{l}37^{\circ} 30^{\prime} \mathrm{N} \\
142^{\circ} 30^{\prime} \mathrm{E}\end{array}$ & 5 & & $-50.6 \pm 3.1$ & & & \\
\hline & & 20 & & & $0.292 \pm 0.027$ & $0.135 \pm 0.013$ & \\
\hline & & 50 & $0.96 \pm 0.09$ & & $0.117 \pm 0.011$ & $0.135 \pm 0.013$ & $0.84 \pm 0.08$ \\
\hline \multirow[t]{5}{*}{22} & $\begin{array}{l}38^{\circ} 00^{\prime} \mathrm{N} \\
142^{\circ} 30^{\prime} \mathrm{E}\end{array}$ & 8 & & & $0.836 \pm 0.052$ & $0.841 \pm 0.060$ & \\
\hline & & 10 & & & $0.217 \pm 0.016$ & $0.203 \pm 0.016$ & \\
\hline & & 20 & & & $0.087 \pm 0.009$ & $0.083 \pm 0.009$ & \\
\hline & & 50 & $0.78 \pm 0.09$ & & $0.122 \pm 0.009$ & $0.138 \pm 0.010$ & $0.67 \pm 0.08$ \\
\hline & & 100 & & & $0.053 \pm 0.007$ & $0.052 \pm 0.008$ & \\
\hline \multirow[t]{4}{*}{24} & $\begin{array}{l}38^{\circ} 00^{\prime} \mathrm{N} \\
142^{\circ} 00^{\prime} \mathrm{E}\end{array}$ & 8 & & & $0.064 \pm 0.009$ & $0.054 \pm 0.007$ & \\
\hline & & 50 & & & $0.215 \pm 0.013$ & $0.201 \pm 0.014$ & \\
\hline & & 75 & & & $0.091 \pm 0.009$ & $0.094 \pm 0.009$ & \\
\hline & & 130 & & & $0.023 \pm 0.006$ & $0.029 \pm 0.005$ & \\
\hline \multirow[t]{6}{*}{25} & $\begin{array}{l}37^{\circ} 31^{\prime} \mathrm{N} \\
141^{\circ} 27^{\prime} \mathrm{E}\end{array}$ & 5 & & $-38.5 \pm 3.2$ & & & \\
\hline & & 10 & & & $0.968 \pm 0.054$ & $1.120 \pm 0.065$ & \\
\hline & & 20 & $1.28 \pm 0.09$ & & $0.225 \pm 0.018$ & $0.221 \pm 0.019$ & $0.68 \pm 0.07$ \\
\hline & & 50 & & & & $0.057 \pm 0.012$ & \\
\hline & & 90 & & & $0.083 \pm 0.009$ & $0.064 \pm 0.009$ & \\
\hline & & 100 & $0.96 \pm 0.08$ & & $0.120 \pm 0.036$ & $0.091 \pm 0.030$ & $1.24 \pm 0.1$ \\
\hline \multirow[t]{6}{*}{26} & $\begin{array}{l}37^{\circ} 00^{\prime} \mathrm{N} \\
141^{\circ} 24^{\prime} \mathrm{E}\end{array}$ & 7 & $0.75 \pm 0.06$ & & $0.453 \pm 0.031$ & $0.441 \pm 0.034$ & $0.20 \pm 0.02$ \\
\hline & & 20 & & & $0.368 \pm 0.023$ & $0.386 \pm 0.026$ & \\
\hline & & 50 & $0.68 \pm 0.03$ & & $0.256 \pm 0.012$ & $0.241 \pm 0.012$ & $0.33 \pm 0.02$ \\
\hline & & 75 & $0.73 \pm 0.02$ & & $0.167 \pm 0.013$ & $0.188 \pm 0.015$ & $0.46 \pm 0.02$ \\
\hline & & 90 & $0.62 \pm 0.03$ & & $0.085 \pm 0.009$ & $0.086 \pm 0.009$ & $0.85 \pm 0.04$ \\
\hline & & 100 & $1.22 \pm 0.03$ & & $0.064 \pm 0.006$ & $0.072 \pm 0.007$ & $2.00 \pm 0.06$ \\
\hline
\end{tabular}




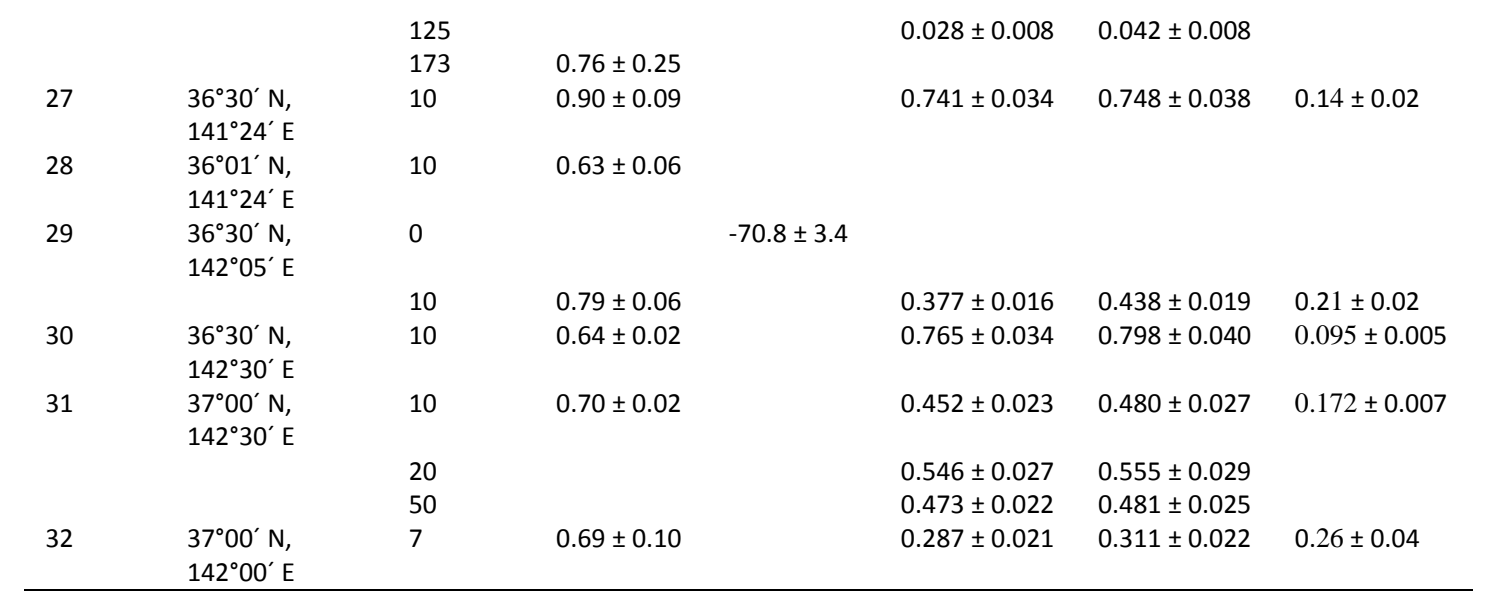

880

881

882

883

884

885

886

887

888

889

890

891

892

893

894

895

896

897

898

899

900

901 


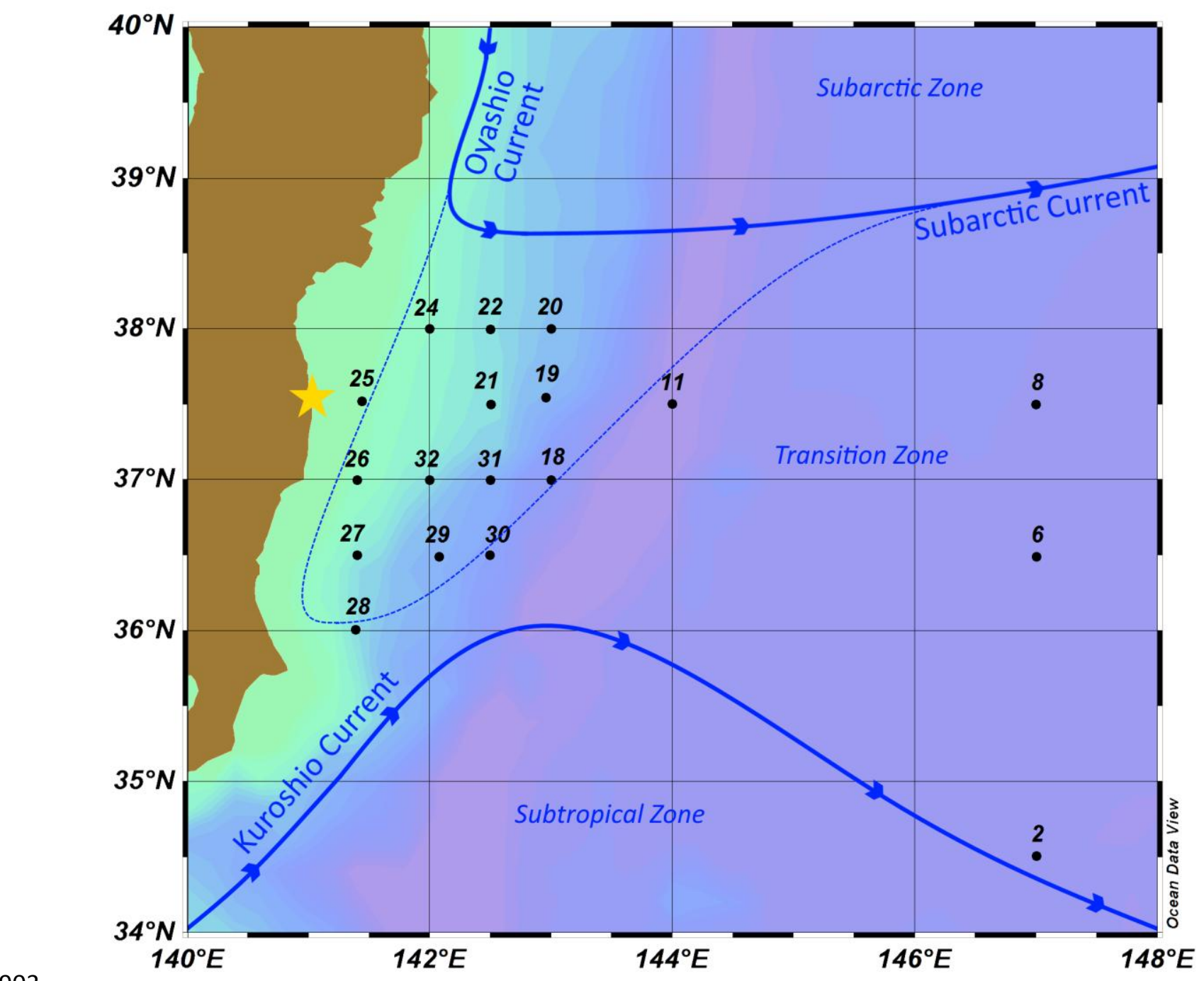

Fig. 1a. Locations of water sampling stations in the western North Paciifc Ocean during the 905 KoK expedition used in this study. Fukushima Dai-ichi NPP accident location is indicated 906 with the star. Approximate positions of the Kuroshio and Oyashio Currents are shown as well. 907 The dashed line represents the southward intrusion of the Oyashio Current (Tatebe and 908 Yasuda, 2004). 


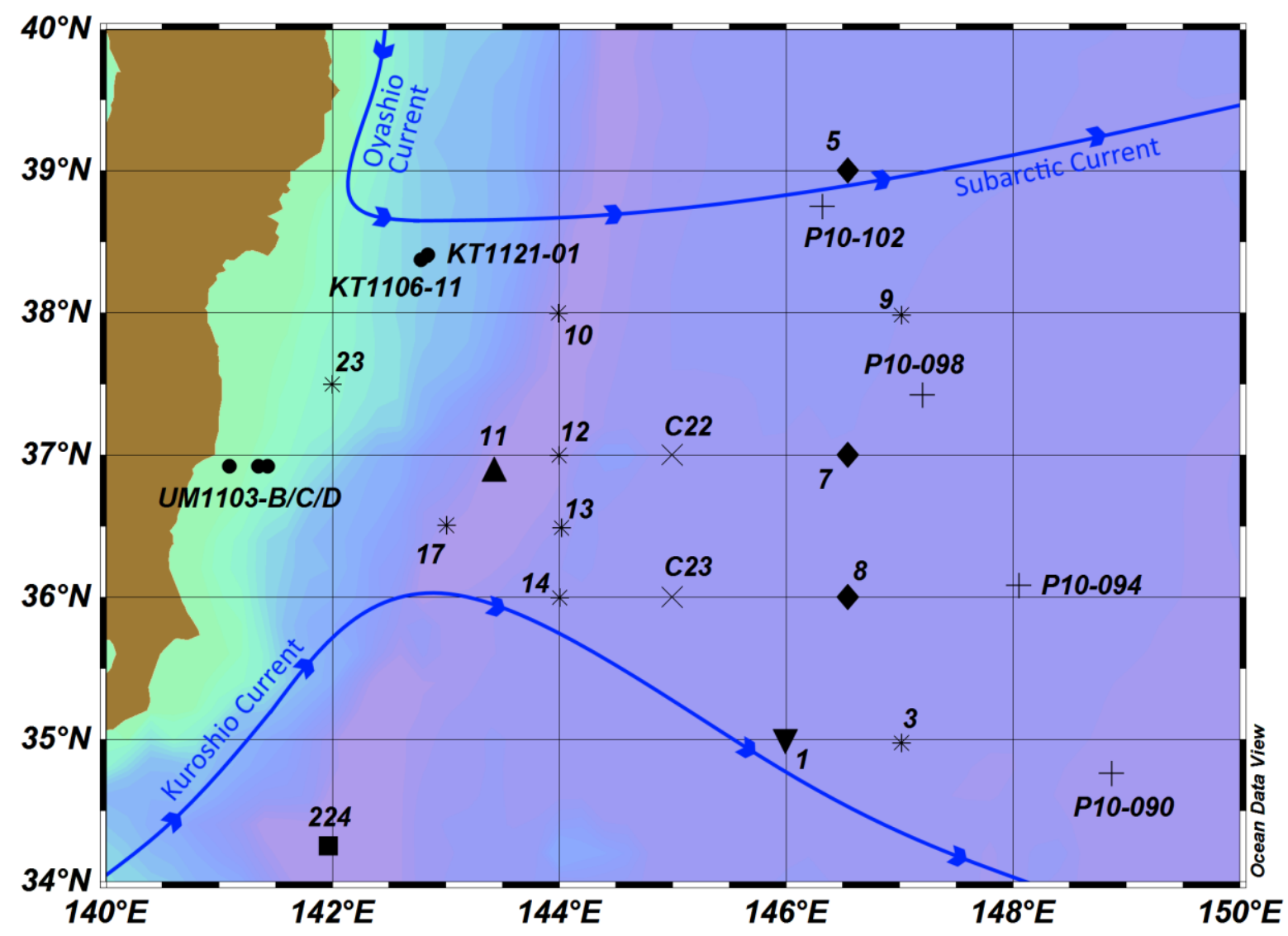

911 Fig. 1b. Locations of sampling stations used for data comparison: • - UM11 and KT11

912 stations sampled for ${ }^{137} \mathrm{Cs}$ in 2011 (Aoyama et al., 2016a); * - selected KoK stations sampled 913 for ${ }^{137} \mathrm{Cs}$ in June 2011 (Buesseler et al., 2012); X - KH93 stations sampled for ${ }^{14} \mathrm{C}$ in 1993

914 (Aramaki et al., 2005); - - GEOSECS station sampled for ${ }^{3} \mathrm{H}$ (Ostlund et al., 1987) and for

$915{ }^{14} \mathrm{C}$ in 1973 (Stuiver and Ostlund, 1983); $\boldsymbol{\nabla}$ - IAEA 97 station sampled in 1997 for ${ }^{137} \mathrm{Cs}$

916 (Povinec et al., 2003), ${ }^{3} \mathrm{H}$ (Povinec et al., 2010) and ${ }^{14} \mathrm{C}$ (Povinec et al., 2004c); + - P10-

917 stations sampled for ${ }^{137} \mathrm{Cs}$ in 2012 (Kumamoto et al., 2015); - RGS stations sampled for

$918{ }^{137} \mathrm{Cs}$ in 2012 (Ramzaev et al., 2014); $\boldsymbol{\Delta}$ - KH88 station sampled for ${ }^{3} \mathrm{H}$ in 1988 (Watanabe et

919 al., 1991; The KH85 station sampled for ${ }^{14} \mathrm{C}$ in 1985 (43 ${ }^{\circ} 00^{\prime} \mathrm{N} 150^{\circ} 14^{\prime} \mathrm{E}$; Tsunogai et al.,



921 2002) were situated outside of the KoK region. 
923

924

925

926

927

928

929

930

931

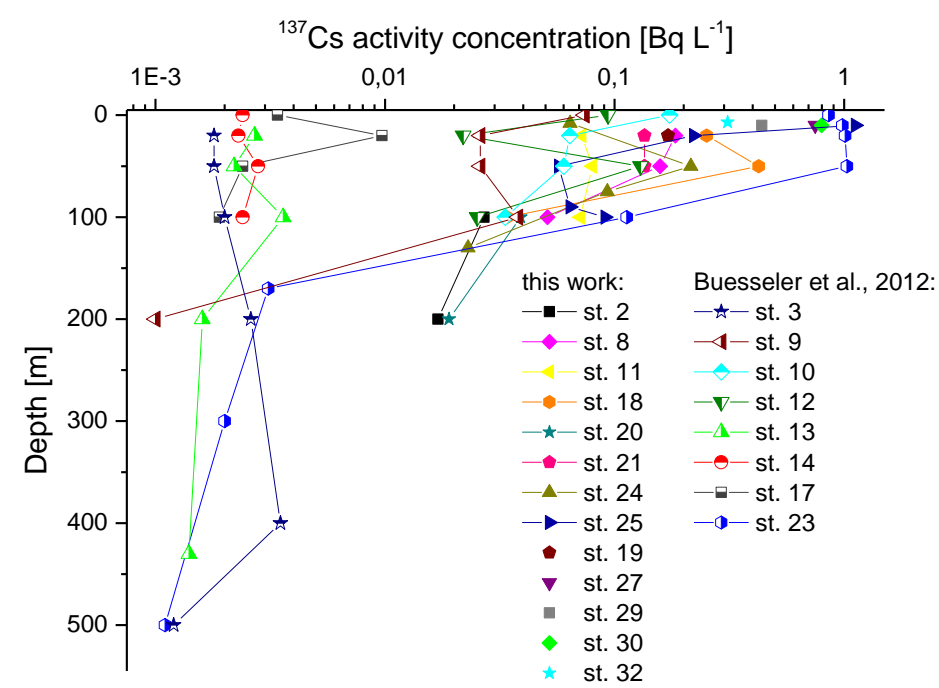

Fig. 2a. ${ }^{137}$ Cs activity concentration in seawater samples collected offshore Fukushima NPP during the KoK cruise, compared with published data measured during the KoK cruise by Buesseler et al. (2012). For locations of the sampling stations see Figs. 1a, b.

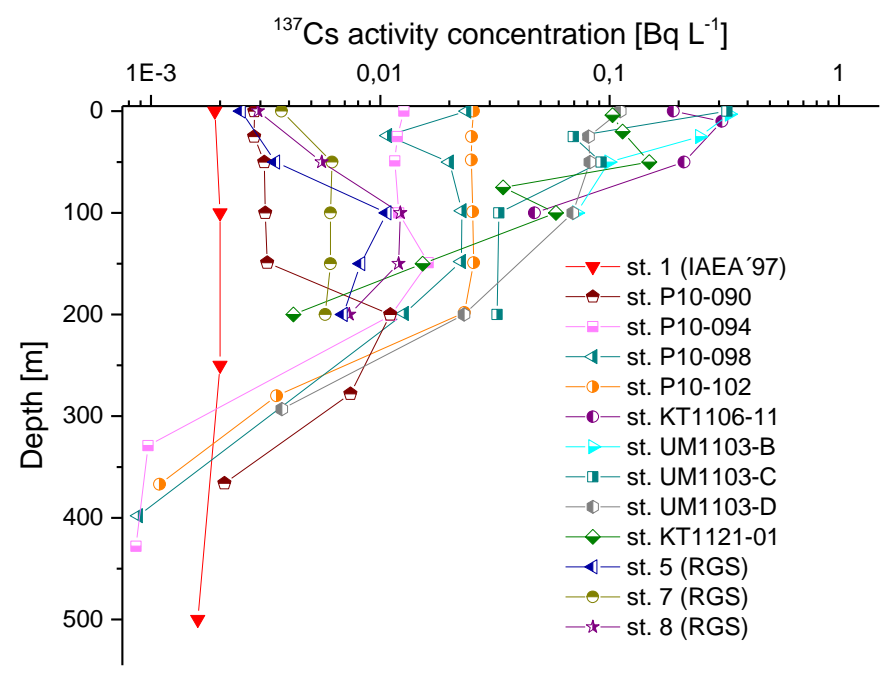

Fig. 2b. ${ }^{137}$ Cs activity concentration in seawater samples collected offshore Fukushima NPP during the KoK cruise (decay corrected to June 2011), compared with published data measured during the IAEA'97 cruise (Povinec et al., 2003), the RGS cruise (Ramzaev et al., 2014), the P10 cruise (Kumamoto et al., 2015) and the UM11 and KT11 cruises (Aoyama et al. (2016a). For locations of the sampling stations see Figure $1 \mathrm{~b}$. 


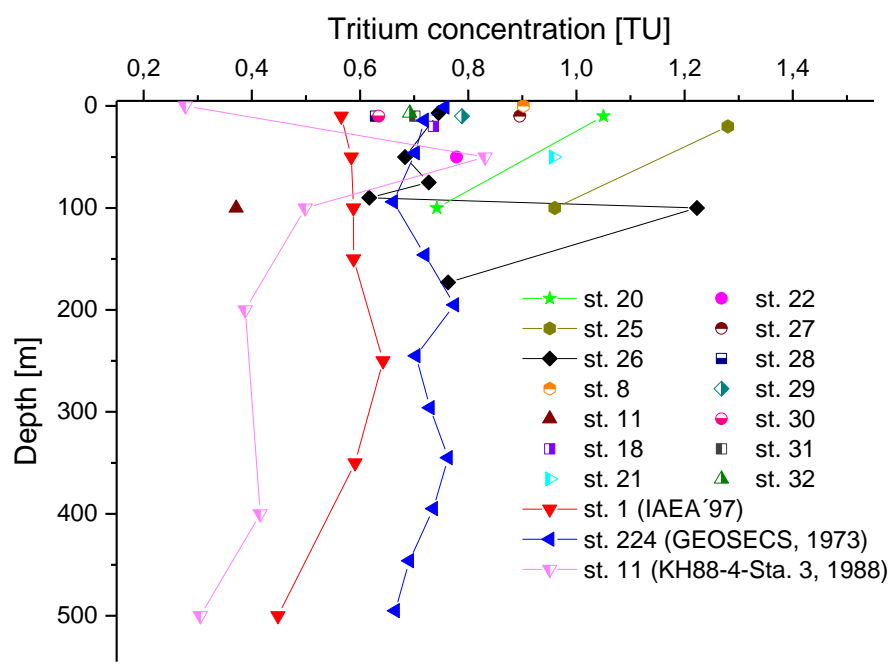

Fig. 3. Tritum concentration in seawater samples collected offshore Fukushima during the KoK cruise (decay corrected to June 2011), compared with the results from the GEOSECS (Ostlund et al., 1987), KH88 (Watanabe et al., 1991) and IAEA'97 (Povinec et al., 2003) expeditions. For locations of the sampling stations see Figure $1 \mathrm{~b}$.

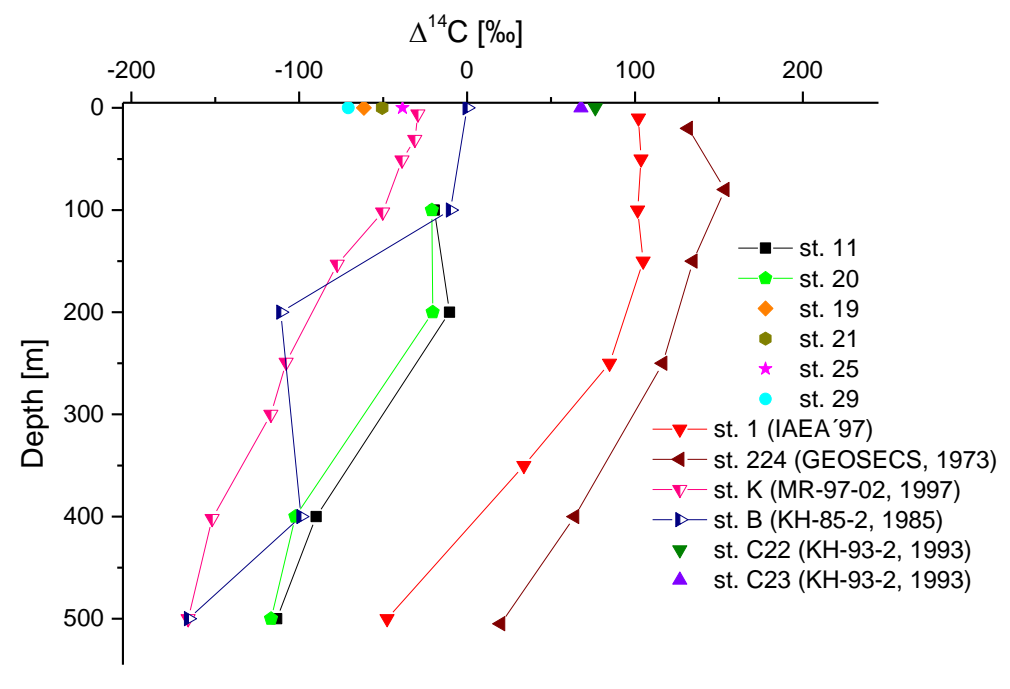

Fig. 4. Radiocarbon concentration in seawater samples collected offshore Fukushima during the KoK cruise (decay corrected to June 2011), compared with the results from the GEOSECS (Stuiver and Otlund, 1983), IAEA'97 (Povinec et al., 2004c), KH-85 (Tsunogai et al., 1995), KH93 (Aramaki et. al., 2005) and MR97 (Kumamoto et al., 2002) expeditions. For locations of the sampling stations see Figure $1 \mathrm{~b}$. 